\title{
Functionalized rare earth-doped nanoparticles for breast cancer nanodiagnostic using fluorescence and CT imaging
}

\author{
Akhil Jain ${ }^{1,2,3}$, Pierrick G. J. Fournier ${ }^{1}$, Vladimir Mendoza-Lavaniegos ${ }^{4,5}$, Prakhar Sengar ${ }^{1,2,3}$, \\ Fernando M. Guerra-Olvera', Enrique Iñiguez ${ }^{4,5}$, Thomas G. Kretzschmar ${ }^{4,5}$, Gustavo A. Hirata ${ }^{3}$ \\ and Patricia Juárez ${ }^{1 *}$ (1)
}

\begin{abstract}
Background: Breast cancer is the second leading cause of cancer death among women and represents $14 \%$ of death in women around the world. The standard diagnosis method for breast tumor is mammography, which is often related with false-negative results leading to therapeutic delays and contributing indirectly to the development of metastasis. Therefore, the development of new tools that can detect breast cancer is an urgent need to reduce mortality in women. Here, we have developed $\mathrm{Gd}_{2} \mathrm{O}_{3}: \mathrm{Eu}^{3+}$ nanoparticles functionalized with folic acid (FA), for breast cancer detection.

Results: $\mathrm{Gd}_{2} \mathrm{O}_{3}: \mathrm{Eu}^{3+}$ nanoparticles were synthesized by sucrose assisted combustion synthesis and functionalized with FA using EDC-NHS coupling. The FA-conjugated $\mathrm{Gd}_{2} \mathrm{O}_{3}: \mathrm{Eu}^{3+}$ nanoparticles exhibit strong red emission at $613 \mathrm{~nm}$ with a quantum yield of $\sim 35 \%$. In vitro cytotoxicity studies demonstrated that the nanoparticles had a negligible cytotoxic effect on normal 293T and T-47D breast cancer cells. Cellular uptake analysis showed significantly higher internalization of FA-conjugated RE nanoparticles into T-47D cells (Fol/ ${ }^{\text {hi }}$ ) compared to MDA-MB-231 breast cancer cells $\left(F o / r^{\circ}\right)$. In vivo confocal and $\mathrm{CT}$ imaging studies indicated that FA-conjugated $\mathrm{Gd}_{2} \mathrm{O}_{3}$ : Eu ${ }^{3+}$ nanoparticles accumulated more efficiently in T-47D tumor xenograft compared to the MDA-MB-231 tumor. Moreover, we found that FAconjugated $\mathrm{Gd}_{2} \mathrm{O}_{3}: \mathrm{Eu}^{3+}$ nanoparticles were well tolerated at high doses $(300 \mathrm{mg} / \mathrm{kg})$ in CD1 mice after an intravenous injection. Thus, FA-conjugated $\mathrm{Gd}_{2} \mathrm{O}_{3}: \mathrm{Eu}^{3+}$ nanoparticles have great potential to detect breast cancer.
\end{abstract}

Conclusions: Our findings provide significant evidence that could permit the future clinical application of FA-conjugated $\mathrm{Gd}_{2} \mathrm{O}_{3}: \mathrm{Eu}^{3+}$ nanoparticles alone or in combination with the current detection methods to increase its sensitivity and precision.

Keywords: Breast cancer, Cancer detection, Luminescent nanoparticles, Folate receptor

\section{Background}

Nanoparticles have emerged as potential tools for the diagnosis and treatment of cancer due to their selective accumulation in cancer tissue via enhanced permeation and retention (EPR) effect [1]. Due to the potential

\footnotetext{
${ }^{*}$ Correspondence: pjuarez@cicese.mx

${ }^{1}$ Biomedical Innovation Department, Centro de Investigación Cientíica y de Educación Superior de Ensenada (CICESE), Carretera Ensenada-Tijuana No. 3918, Zona Playitas, C.P. 22860 Ensenada, B.C., Mexico

Full list of author information is available at the end of the article
}

benefits of nanoparticles in cancer, various multimodality nanoparticle platforms have been developed for cancer imaging using computed tomography $(\mathrm{CT})$, positron emission tomography (PET), and single-photon emission computed tomography (SPECT) [2-4]. However, due to the lack of spatial resolution and low sensitivity, most of these imaging techniques fail to detect cancer at an early stage $[5,6]$. Therefore, a more sensitive dual imaging probe is needed for early cancer diagnosis that can complement clinically approved modality such as CT. On the other hand, fluorescent imaging is emerging as a 
powerful method to detect cancer at an early stage of the disease due to its high resolution $(0.5-3 \mu \mathrm{m})$ and sensitivity $[7,8]$. Besides fluorescence imaging is a versatile tool for biomedical imaging, therefore there is an increased demand for luminescent materials. Various luminescent nanoparticles have been developed for cancer imaging including quantum dots (QD) and inorganic nanoparticles functionalized with organic dyes $[9,10]$. However, toxicity issues associated to QD and photobleaching of organic dyes limit their clinical applications [11, 12]. In contrast, rare-earth (RE) doped nanoparticles are of interest for in vivo imaging due to various advantages such as low cytotoxicity, high quantum yield, longer lifetime, narrow emission lines, large Stokes shifts, photostability and high chemical stability [13, 14]. Therefore, RE-doped luminescent nanoparticles have great potential as a biomarker tool for biomedical purposes.

Synthesis of various $\mathrm{Eu}^{3+}: \mathrm{RE}_{2} \mathrm{O}_{3}$ luminescent nanomaterials using $\mathrm{Y}, \mathrm{La}$ or $\mathrm{Gd}$ as $\mathrm{RE}$ element has been reported [15-17]. Among them nanoparticles with $\mathrm{Gd}_{2} \mathrm{O}_{3}$ are of great interest due to its low phonon energy [18], proton relaxation [19] and scintillation [20] properties making it an excellent candidate for fluorescence imaging, MRI and $\mathrm{X}$-ray CT, respectively. These $\mathrm{Eu}^{3+}$ doped $\mathrm{Gd}_{2} \mathrm{O}_{3}$ nanoparticles with different sizes and morphologies have been utilized in a variety of applications such as in optical displays, solar cells and in vivo imaging [21-23].

Physicochemical properties such as size and shape of the nanoparticles are very important for passive targeting of tumor vasculature through EPR effect. Studies elucidating the behavior of nanoparticle size, shape and surface charge on bio-distribution and biocompatibility in vivo are present in the literature [24, 25]. There are now various evidence that specificity and efficiency of passively targeted nanoparticle can be enhanced by surface modification with a specific targeting ligand [26, 27]. Therefore, for in vivo application introduction of surface modification is preferable for improving the dispersion properties and targeting potential [28].

Folate receptor alpha (FR) is highly expressed in some forms of cancers such as ovarian cancer and in up to $80 \%$ of breast cancer tumors [29]. Therefore, the addition of folic acid molecule has been used to increase the specificity of nanoparticles or drugs for cancer cells. The strong affinity of FR for its ligand folate, permit the internalization via receptor-mediated endocytosis and specific uptake FA-functionalized nanoparticles [30-32]. Hence, folic acid represents an important ligand that could be used clinically for specific targeting of breast cancer. A variety of RE-doped nanoparticles has been proposed for targeted cancer cell imaging. For instance, Setua et al. [33] reported higher cellular uptake of FA conjugated fluorescent magnetic RE nanocrystals on FR positive human nasopharyngeal carcinoma cells (KB) compared to FR depressed KB and FR negative lung cancer cells A549 control cells. Stefanakis and Ghanotakis [34] demonstrated specific targeting of HeLa cells using $\mathrm{Tb}_{2}(\mathrm{OH})_{5} \mathrm{NO}_{3}$-FA nanoparticles doped with Europium.

In this study, $\mathrm{Gd}_{2} \mathrm{O}_{3}: \mathrm{Eu}^{3+}$ nanoparticles were produced using sucrose combustion synthesis. $\mathrm{Gd}_{2} \mathrm{O}_{3}: \mathrm{Eu}^{3+}$ nanoparticles (N1-Bare) were then coated with aminosilane coupling agent APTMS to introduce amine groups (N2-APTMS). Finally, these amine groups were conjugated to the carboxyl groups of FA molecule using EDCNHS coupling mechanism to produce FA-functionalized $\mathrm{Gd}_{2} \mathrm{O}_{3}: \mathrm{Eu}^{3+}$ nanoparticles (N3-FA). We examined the biocompatibility and potential of folic acid-functionalized $\mathrm{Gd}_{2} \mathrm{O}_{3}: \mathrm{Eu}^{3+}$ nanoparticles to target breast cancer cells in vitro and in vivo using a xenograft model by dual-modal fluorescence and CT imaging. The targeting ability and toxicity of these folic acid-functionalized $\mathrm{Gd}_{2} \mathrm{O}_{3}: \mathrm{Eu}^{3+}$ nanoparticles is compared with N1-Bare and/or N2-APTMS. Our findings suggest that folic acidfunctionalized $\mathrm{Gd}_{2} \mathrm{O}_{3}: \mathrm{Eu}^{3+}$ nanoparticles are promising candidates for the detection of breast cancer.

\section{Methods}

\section{Materials}

Gadolinium nitrate $\left(\mathrm{Gd}\left(\mathrm{NO}_{3}\right)_{2} \cdot 6 \mathrm{H}_{2} \mathrm{O}, 99.9 \%\right)$ and europium nitrate $\left(\mathrm{Eu}\left(\mathrm{NO}_{3}\right)_{2} \cdot 6 \mathrm{H}_{2} \mathrm{O}, 99.9 \%\right)$ were purchased from Aldrich and Alfa Aesar, respectively. Sucrose $\left(\mathrm{C}_{12} \mathrm{H}_{22} \mathrm{O}_{11}, \quad 99.5 \%\right), \quad 3$-aminopropyltrimethoxysilane (APTMS, 97\%), toluene (ACS grade, $\geq 99.5 \%$ ), folic acid ( $\geq 97 \%), N$-(2-dimethylaminopropyl)- $N$-ethylcarbodiimide hydrochloride (EDC), $N$-hydroxysuccinimide (NHS, 98\%), dimethyl sulfoxide (DMSO, $\geq 99.5 \%$ ), $\mathrm{KBr}$ (FTIR grade, $99 \%$ ) were purchased from Sigma-Aldrich.

\section{Synthesis of $\mathrm{Gd}_{2} \mathrm{O}_{3}: \mathrm{Eu}^{3+}$ nanoparticles $(\mathrm{Gd} / \mathrm{Eu}=0.95 / 0.05)$ (N1-Bare) \\ $\mathrm{Gd}_{2} \mathrm{O}_{3}: \mathrm{Eu}^{3+}$ nanoparticles were synthesized by sucrose} combustion synthesis as previously reported [35]. Stoichiometric amounts of the metal precursors and fuels were weighed and mixed with $30 \mathrm{ml}$ of distilled water under magnetic stirring for $25 \mathrm{~min}$ at room temperature. The obtained transparent solution was transferred to a preheated muffle furnace maintained at $380^{\circ} \mathrm{C}$. The solution was kept inside the furnace for $25 \mathrm{~min}$ for the complete decomposition of fuel. The synthesis was completed with the ignition of the fuel. The obtained highly porous black powder was gently crushed with a pestle and mortar. Finally, the powder was annealed at $1000{ }^{\circ} \mathrm{C}$ for $3 \mathrm{~h}$ to obtain a white nanocrystalline $\mathrm{Gd}_{2} \mathrm{O}_{3}: \mathrm{Eu}^{3+}$ powder. 


\section{Synthesis of $\mathrm{Gd}_{2} \mathrm{O}_{3}: \mathrm{Eu}^{3+} @$ APTMS nanoparticles (N2-APTMS)}

Freshly prepared $\mathrm{Gd}_{2} \mathrm{O}_{3}: \mathrm{Eu}^{3+}$ nanoparticles were dispersed in $80 \mathrm{ml}$ of toluene with the help of probe sonication. After $30 \mathrm{~min}$, APTMS was introduced in an equimolar ratio with $\mathrm{Gd}_{2} \mathrm{O}_{3}: \mathrm{Eu}^{3+}$ nanoparticles and placed under magnetic stirring, during $20 \mathrm{~h}$, for efficient grafting of silane layer. The temperature of the reaction was then increased to $80{ }^{\circ} \mathrm{C}$ for $4 \mathrm{~h}$ for the formation of solid bonds between nanoparticle surface and silane groups. The nanoparticles were washed 4 times with ethanol and centrifuged at $6000 \mathrm{rpm}$ for $15 \mathrm{~min}$ and dried at $65^{\circ} \mathrm{C}$ overnight.

\section{Synthesis of folic acid-functionalized $\mathrm{Gd}_{2} \mathrm{O}_{3}: \mathrm{Eu}^{3+}$ nanoparticles (N3-FA)}

For the surface functionalization with FA, $0.05 \mathrm{M}$ folic acid was prepared in DMSO under magnetic stirring. For the activation of carboxyl groups present in FA molecule, freshly prepared $1 \mathrm{ml}$ EDC $(75 \mathrm{mM})$ and $1 \mathrm{ml}$ NHS $(150 \mathrm{mM})$ in DMSO were added to $30 \mathrm{ml}$ the mixture. The reaction was allowed to continue for $4 \mathrm{~h}$ under an $\mathrm{N}_{2}$ atmosphere in the dark. Then, APTMS coated $\mathrm{Gd}_{2} \mathrm{O}_{3}: \mathrm{Eu}^{3+}$ nanoparticles (N2-APTMS) dispersed in PBS (pH 7.4) were introduced into the activated folic acid solution. The reaction was stirred for another $24 \mathrm{~h}$ under similar condition. Lastly, the nanoparticles were washed several times with DI water and ethanol and centrifuged at $6000 \mathrm{rpm}$ for $15 \mathrm{~min}$ and dried at $65^{\circ} \mathrm{C}$ overnight.

\section{Characterization}

\section{Crystalline structure}

The Crystal phase of $\mathrm{Gd}_{2} \mathrm{O}_{3}: \mathrm{Eu}^{3+}$ nanoparticles was characterized using a Philips X'pert X-ray diffractometer with a $\mathrm{Cu} \mathrm{K \alpha}$ radiation $(\lambda=0.15406 \mathrm{~nm})$, scanned over a $2 \theta$ range of $20-80^{\circ}$.

\section{Size and morphology}

Transmission electron microscopy (TEM) images were acquired using JEOL-JEM-2010 operated at $200 \mathrm{kV}$. The size of nanoparticles was defined by measuring the diameters of 240 different nanoparticles. The samples were prepared by dispersing the nanoparticles in an ultrasonic bath for $15 \mathrm{~min}$ and then placing a few drops of the sample on 400 mesh carbon-coated copper grids.

\section{Surface analysis}

X-ray photoelectron spectroscopy (XPS) spectra of different $\mathrm{Gd}_{2} \mathrm{O}_{3}: \mathrm{Eu}^{3+}$ nanoparticle system (N1-bare, N2-APTMS, and N3-FA) was obtained by a SPECS system equipped with a PHOIBOS WAL analyzer using $\mathrm{AlK}_{\alpha}$ radiation $(\mathrm{hv}=1486.6 \mathrm{eV})$. The scale of the spectrometer was calibrated with the reference binding energy of $\mathrm{Ag} 3 \mathrm{~d}_{5 / 2}$. Fourier transform infrared spectroscopy (FTIR) spectra were recorded using a Nicolet 6700, Thermo Scientific infrared spectroscope.

\section{Thermal analysis}

Thermogravimetry analysis (TGA) was carried out on a TA Q600, TA Instruments under Nitrogen atmosphere, with a heating rate of $10^{\circ} \mathrm{C} / \mathrm{min}$.

\section{Hydrodynamic diameter and zeta potential (६)}

Particle size distribution and zeta potential measurements were carried out using Horiba Scientific, nanoparticle analyzer SZ-100. An aqueous suspension solution of the nanoparticles $(0.25 \mathrm{mg} / \mathrm{ml})$ was prepared in PBS $(\mathrm{pH}$ 7.4) by sonication in a water bath for $5 \mathrm{~min}$. All the measurements were carried out at an equilibrium temperature of $25^{\circ} \mathrm{C}$ and were repeated three times.

\section{Photoluminescence spectroscopy, quantum yield and decay time}

Photoluminescence (PL) spectra and fluorescence lifetime were recorded with Hitachi F-7000 fluorescence spectrophotometer at $254 \mathrm{~nm}$ excitation wavelength. This excitation wavelength was chosen as it produced highest PL emission intensity. For the decay time measurements, the chopping speed of $40 \mathrm{~Hz}$ was used on the excitation side. The curves were fitted to a double-exponential function shown in Eq. 1.

$$
I=I_{1} \exp \left(-\frac{t}{\tau 1}\right)+I_{2} \exp \left(-\frac{t}{t 2}\right)
$$

where $\tau_{1}$ and $\tau_{2}$ are the decay lifetimes, and $I_{1}$ and $I_{2}$ are the weighing parameter obtained from the data fitting. For the double-exponential decay, the average fluorescence lifetime $\left(\tau_{\mathrm{av}}\right)$ was calculated using the following equation:

$$
\tau_{a v}=\sum_{i=1}^{N} \frac{\alpha_{i} \tau_{i}^{2}}{\alpha_{i} \tau_{i}}
$$

PL quantum yield (QY) of $\mathrm{Gd}_{2} \mathrm{O}_{3}: \mathrm{Eu}^{3+}$ nanoparticles dispersed in aqueous solution was determined by using Rhodamine 6G as a reference standard (QY in ethanol $=95 \%$ ), as previously reported [36]. A standard curve of PL intensity vs. absorbance (at different concentrations) was generated using multiple standards (OD values between 0.1 and 1) of Rhodamine $6 \mathrm{G}$ and $\mathrm{Gd}_{2} \mathrm{O}_{3}$ : $\mathrm{Eu}^{3+}$ nanoparticles. The value of QY was calculated with the following formula:

$$
\mathrm{Q}=\mathrm{Q}_{\mathrm{R}}\left[\mathrm{m} / \mathrm{m}_{\mathrm{R}}\right]\left[\mathrm{n}^{2} / \mathrm{n}_{\mathrm{R}}^{2}\right]
$$


where $\mathrm{Q}_{\mathrm{R}}=$ known quantum yield of Rhodamine 6G; $\mathrm{m}$ and $\mathrm{m}_{\mathrm{R}}=$ Slope of the PL intensity vs. absorption curve of the sample and the reference standard, respectively; $\mathrm{n}$ and $n_{R}=$ refractive index of the solvents in which reference and the sample was dispersed: ethanol is 1.359 and PBS is 1.333 at room temperature. All the measurements were performed using a $10 \mathrm{~mm}$ rectangular quartz cell (Starna Cells Inc.) and repeated at least three times.

\section{Cell culture}

Human cancer cell lines MDA-MB-231, T-47D, 293T, and PC-3 cells were obtained from American Type Culture Collection (ATCC, USA). MDA-MB-231, MCF-7, and 293T cells were maintained in DMEM (Cellgro), and T-47D and PC-3 cells were cultivated in RPMI-1640, medium (Cellgro), all supplemented with 10\% FBS (Biowest), penicillin, streptomycin and amphotericin B (Cellgro). Cells were maintained at $37^{\circ} \mathrm{C}$ in an incubator with humidified atmosphere, containing $5 \% \mathrm{CO}_{2}$.

\section{In vitro cytotoxicity assay}

The cytotoxicity of $\mathrm{Gd}_{2} \mathrm{O}_{3}: \mathrm{Eu}^{3+}$ nanoparticles was evaluated using a colorimetric 3-(4,5-dimethylthiazol-2-yl)2,5-diphenyltetrazolium bromide (MTT) assay. Human embryonic kidney cells $293 \mathrm{~T}$ and breast cancer cell T-47D were seeded into a 96-well plate at a density of $10^{5}$ cells and cultured for $24 \mathrm{~h}$. The culture medium was replaced with fresh medium containing various concentrations of unmodified (N1-Bare), APTMS coated (N2-APTMS) and folic acid-conjugated (N3-FA) $\mathrm{Gd}_{2} \mathrm{O}_{3}: \mathrm{Eu}^{3+}$ nanoparticles $(6.25-100 \mu \mathrm{g} / \mathrm{ml})$. After incubation for $24 \mathrm{~h}$ or $48,20 \mu \mathrm{l}$ of MTT solution $(5 \mathrm{mg} / \mathrm{ml}$ in PBS) was added and incubated for $5 \mathrm{~h}$. To stop the reaction and dissolve the MTT-formazan product, $100 \mu \mathrm{l}$ of a stop buffer $(0.01 \mathrm{M} \mathrm{HCl}$ containing $10 \%$ SDS) was added, and the plates were incubated for $20 \mathrm{~h}$. The absorbance at $570 \mathrm{~nm}$ was measured using an Epoch microplate reader (Biotek). The cell viability as a percentage of the untreated control cells was calculated using the following formula:

\section{(Mean absorbance value of the treated group / Mean absorbance value of control) $\times 100$}

\section{Gene expression analysis: quantitative real-time PCR}

Folr1 mRNA level was determined using a two-step quantitative reverse transcriptase- real-time PCR (RTqPCR). MDA-MB-231, MCF-7, T-47D, $293 \mathrm{~T}$ and PC-3 cells were seeded in a 12-well plate at a density of $10^{4}$ cells per well. Total RNA was extracted using the Gen-Elute total RNA extraction kit (Sigma-Aldrich) and reverse transcribed using SuperScript II Reverse Transcriptase (Thermo Scientific). Finally, the qPCR reactions were performed in triplicates using $10 \mathrm{ng}$ of cDNA. The relative expression of Folr1 mRNA in different human cancer cell lines was quantified by comparing it with the standard curve obtained by qPCR of cDNA pool of different cells. Gene expression of the target gene was normalized using housekeeping gene ribosomal protein L32 (RPL32). The primers were purchased from T4Oligo and were designed using Primer3Plus. The primer sequence used were: Folr1 (forward, GCATTTCATCCAGGACACCT; reverse, GGTGTAGGAGGTGCGACAAT) and RPL 32 (forward, CAGGGTTCGTAGAAGATTCAAGGG; reverse, CTTGGAGGAAACATTGTGAGCGATC).

\section{In-vitro fluorescence imaging and cellular uptake analysis}

Cellular uptake of N3-FA in cancer cells was determined by using a confocal laser-scanning microscope (CLSM). MDA-MB-231 and T-47D cells were cultured in $35 \mathrm{~mm}$ glass bottom dish at a density of $2.5 \times 10^{5}$ cells per plate and cultured for $24 \mathrm{~h}$. The cells were then incubated with culture medium containing N3-FA at a concentration of $25 \mu \mathrm{g} / \mathrm{ml}$ for $2,4,6$, or $8 \mathrm{~h}$. Then, the cells were washed twice with PBS to remove unbound nanoparticles. Subsequently, the cells were fixed with $4 \%$ paraformaldehyde at room temperature for $5 \mathrm{~min}$. The cells were visualized using an Olympus FluoView-FV 1000 confocal microscope at $60 \times$ objective. Cellular uptake of N3-FA nanoparticles was quantified by measuring fluorescent intensity of at least 90 different cells using ImageJ. The fluorescent intensity values were normalized to the total number of cells per field and expressed as corrected total cell fluorescence (CTCF) obtained by applying the following formula:

$$
\begin{aligned}
\mathrm{CTCF}= & \text { Integrated density }-(\text { Area of selected cell } \\
& \times \text { Mean fluorescence of background signal })
\end{aligned}
$$

\section{Animal experiments}

All animal experiments were performed in compliance with the local ethics committee. Male CD1 mice (8-week old) were obtained from Harlan-Envigo and female athymic mice (Crl: NU/NU-nuBR, 6-8 week old) were obtained from the Unidad de Produccion y Experimentación de Animales Laboratorio de la Universidad Autónoma Metropolitana (Campus Xochimilco). Mice were maintained in an Optimice cage system (Animal care Systems), in a controlled environment room (temperature $24{ }^{\circ} \mathrm{C}$ and $12 \mathrm{~h}$ light/dark cycle). Mice received water and food (2018 Teklad Global 18\% protein rodent diet) ad libitum. Mice were acclimated for at least a week before starting the experiments.

\section{Acute toxicity of FA-conjugated $\mathrm{Gd}_{2} \mathrm{O}_{3}: \mathrm{Eu}^{3+}$ nanoparticles (N3-FA) in vivo}

CD1 mice were divided into 6 groups ( $\mathrm{n}=5$ per group) and received intravenous tail vein injection of PBS or a solution of N3-FA in PBS (35, 50, 100, 200, and $300 \mathrm{mg} /$ 
$\mathrm{kg}$ ). After N3-FA administration, body weight, food intake, water intake and behavior patterns were registered daily. Mice were euthanized 7 days after administration of N3-FA in a $\mathrm{CO}_{2}$ chamber, and cervical dislocation was used as a secondary method of euthanasia.

\section{Pharmacokinetic studies Luminescence of FA-conjugated $\mathrm{Gd}_{2} \mathrm{O}_{3}: \mathrm{Eu}^{3+}$ nanoparticle in blood}

For the pharmacokinetics study, CD1 mice were divided into seven groups ( $\mathrm{n}=3$ per group). Mice were administered with N3-FA nanoparticles at a dose of $200 \mathrm{mg} / \mathrm{kg}$ or with PBS. At different time interval up to $24 \mathrm{~h}$, mice were anesthetized by intraperitoneal injection of 5-pentabarbitol and blood was collected using cardiac puncture. Later, the whole blood was diluted in PBS and the presence of FA-conjugated $\mathrm{Gd}_{2} \mathrm{O}_{3}: \mathrm{Eu}^{3+}$ nanoparticles was determined by monitoring the PL spectra using a Hitachi F-7000 fluorescent spectrophotometer.

\section{Biodistribution analysis using confocal microscopy}

To detect FA-conjugated $\mathrm{Gd}_{2} \mathrm{O}_{3}: \mathrm{Eu}^{3+}$ nanoparticles in vivo, selected organs of CD1 mice administered with $\mathrm{N} 3-\mathrm{FA}$ at $200 \mathrm{mg} / \mathrm{kg}$ were extracted immediately after the collection of blood samples ( $2 \mathrm{~h}$ post-injection). For biodistribution analysis, tissue sections of $6 \mu \mathrm{m}$ were prepared using a cryostat and fixed with $4 \%$ paraformaldehyde for $10 \mathrm{~min}$. Nuclei were stained using 4,6-diamidino-2-phenylindole (DAPI, $10 \mu \mathrm{g} / \mathrm{ml}$ ) for $5 \mathrm{~min}$. Later, the tissue sections were analyzed to determine the biodistribution of N3-FA using CLSM.

\section{Biodistribution analysis of nanoparticles in tumor-bearing mice}

Breast cancer tumor xenografts were established by subcutaneous injection of either T-47D cells $\left(5 \times 10^{6}\right.$, $\mathrm{n}=9)$ or MDA-MB-231 cells $\left(2 \times 10^{6}, \mathrm{n}=3\right)$ to each flank of female nude mice (female, 6-8 weeks old). All the mice were fed autoclaved food and water. For the mice receiving T-47D cells, in addition to normal food, they were fed with $2 \mathrm{~g} / \mathrm{kg}$ of chocolate spread containing $5 \mu \mathrm{l}$ of $\beta$-estradiol $(10 \mathrm{nM})$ every day. Tumor growth was monitored using a vernier caliper, and their volume was calculated using the following formula: Volume $=\left[\right.$ length $\left.\times(\text { width })^{2}\right] / 2$. Three and 7 weeks after the inoculation of MDA-MB-231 and T-47D cells, respectively, mice received an intravenous inoculation of PBS, APTMS coated (N2-APTMS, $200 \mathrm{mg} / \mathrm{kg}$ ) and FA-conjugated (N3-FA, $200 \mathrm{mg} / \mathrm{kg}$ ) $\mathrm{Gd}_{2} \mathrm{O}_{3}: \mathrm{Eu}^{3+}$ nanoparticles ( $\mathrm{n}=3$ per group). Organ extraction was performed $2 \mathrm{~h}$ after i.v. of nanoparticles and were prepared for cryosectioning. Biodistribution was analyzed using CLSM as described before and by CT imaging.

\section{$\mu C T$ and image processing}

The scanning of the tumors was done with a SkyScan 2211 nano-CT (Bruker micro-CT, Belgium). The samples were scanned using voltage of $40-50 \mathrm{kV}$, target current of $70 \mu \mathrm{A}(0.1 \mu \mathrm{m}$ Tungsten source), and exposure time of $300-350 \mathrm{~ms}$, with resolution from 2.2 to $3.0 \mu \mathrm{m}$, depending on sample geometry, resulting in $1536 \times 1920$ pixels on a flat panel detector, rotation step of $0.200^{\circ}$, frame averaging of 4 , and $360^{\circ}$ scan to minimize artifacts produced by the combination of high-density $\mathrm{Gd}_{2} \mathrm{O}_{3}: \mathrm{Eu}^{3+}$ nanoparticles and low-density tissue. The reconstructed slices were obtained with NRecon v1.7.1.0 and each time histograms were forced to stay within -750 to $5000 \mathrm{HU}$ (Hounsfield Units). No staining was required. To obtain the ratio of the volume of nanoparticles/volume of the tumor, image-processing scripts were created and run with the native software of the nano-CT (CT Analyser v1.17.7.1; Bruker micro-CT, 2017). The processed volume for each tumor was fixed to $\sim 0.99 \mathrm{~mm}^{3}$ (for comparison purpose) consisting of cylindrical sections with a diameter and height of 1.5 and $0.56 \mathrm{~mm}$, respectively.

\section{Statistical analysis}

Statistical analyses were performed using GraphPad Prism v5.0 software (GraphPad Software, Inc). Comparisons of three or more groups were conducted with a 1-way ANOVA test, followed by a Bonferroni's post-test. For responses that were affected by two variables, a 2-way ANOVA with a Bonferroni's or Tukey post-test was used. Results are expressed as mean \pm SEM and a $\mathrm{P} \leq 0.05$ was considered significant.

\section{Results}

Synthesis and characterization of $\mathrm{Gd}_{2} \mathrm{O}_{3}: \mathrm{Eu}^{3+}$ nanoparticles

$\mathrm{Gd}_{2} \mathrm{O}_{3}: \mathrm{Eu}^{3+}$ nanoparticles were produced using sucrose combustion synthesis and post-annealed at $1000{ }^{\circ} \mathrm{C}$ for $3 \mathrm{~h}$ to improve the crystalline structure. The schematic illustration of synthesis procedure of $\mathrm{Gd}_{2} \mathrm{O}_{3}: \mathrm{Eu}^{3+} @$ APTMS @ FA is presented in Scheme 1. In general, combustion synthesis produces nanoparticles with good crystallinity due to high reaction temperature. XRD pattern of N3-FA was in agreement with JCPDS-03-065-3181, indicating the presence of a cubic crystal phase of $\mathrm{Gd}_{2} \mathrm{O}_{3}$ (Fig. 1a). The presence of an intense and sharp peak with indices (222) suggested the presence of a well crystalline structure. The average crystallite size calculated using Scherrer's formula was $36.89 \pm 0.12 \mathrm{~nm}$ for N3-FA. TEM analysis indicated the presence of a few large agglomerates, probably due to the presence of weak van der Walls forces between the nanoparticles and the average size of N1-Bare was $45 \pm 3.6 \mathrm{~nm}$ (Fig. 1b(i and ii)). After APTMS coating, the silane layer was estimated to be around 
(1)
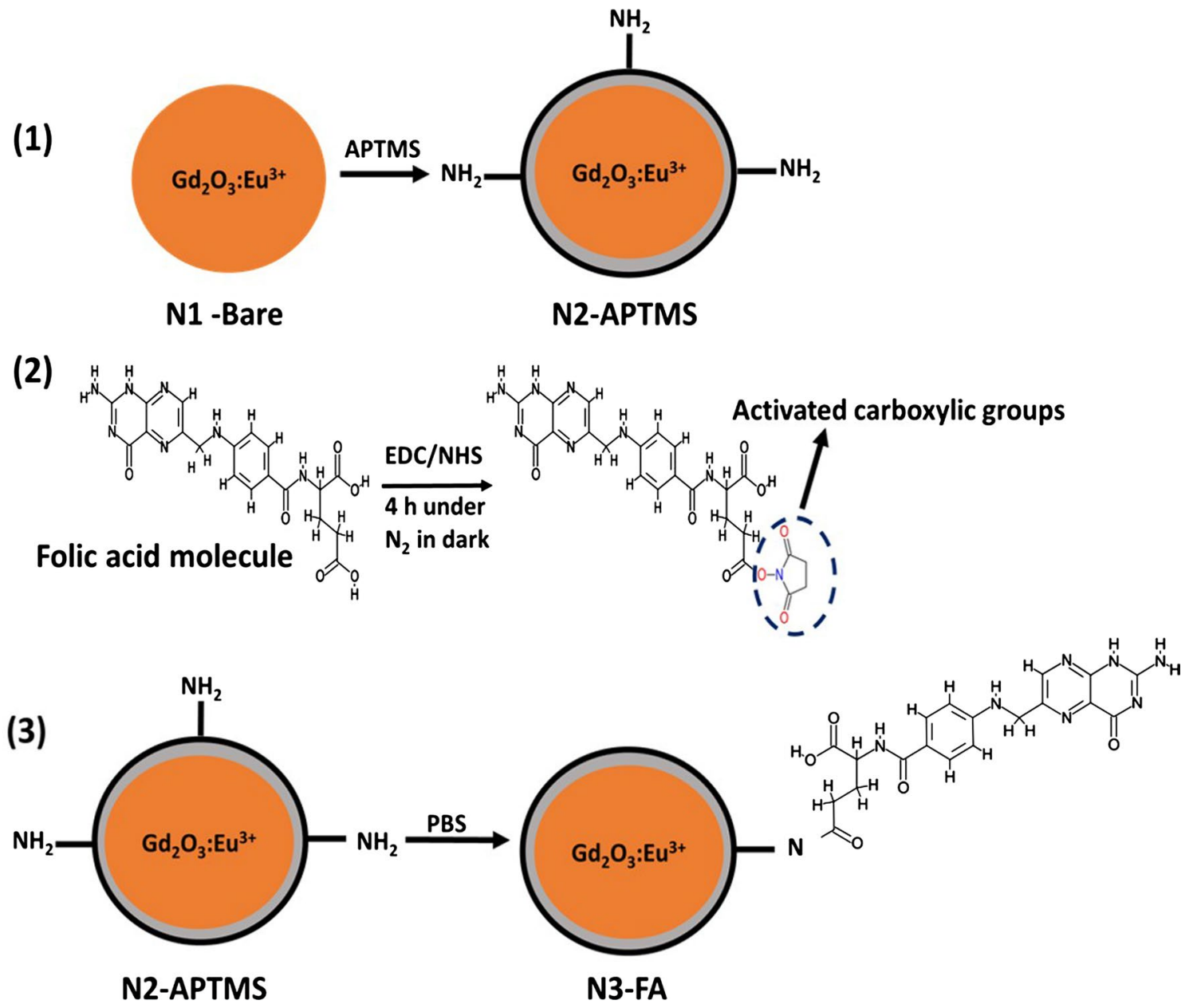

N2-APTMS

Scheme 1 Schematic representation of synthesis procedure involved in the development of folic acid functionalized $\mathrm{Gd}_{2} \mathrm{O}_{3}: \mathrm{Eu}^{3+}$ nanoparticles

$3 \pm 1.5 \mathrm{~nm}$ (Fig. $1 \mathrm{~b}$ (iii and iv)), and the average size was further increased to $55 \pm 6.07 \mathrm{~nm}$ for N3-FA (Fig. 1c).

FTIR measurements were carried out to characterize the surface functional groups present on different $\mathrm{Gd}_{2} \mathrm{O}_{3}: \mathrm{Eu}^{3+}$ nanoparticles (Fig. 2a). A peak at $\sim 543 \mathrm{~cm}^{-1}$ is characteristic of the lattice vibration of Gd-O (peak 1) was detected in all the samples. A well-defined peak at $1029 \mathrm{~cm}^{-1}$ (peak 3) was observed in N2-APTMS due to the formation of $\mathrm{Si}-\mathrm{O}-\mathrm{Si}$ linkage. After APTMS-coating, new peaks appeared in the spectra of N2-APTMS at $1132 \mathrm{~cm}^{-1}$ (peak 4), $1492 \mathrm{~cm}^{-1}$ (peak 5) and $1567 \mathrm{~cm}^{-1}$ (peak 6), characteristics vibration of the $\mathrm{Si}-\mathrm{C}$ groups, the symmetric $-\mathrm{NH}_{3}{ }^{+}$deformation mode and of scissor vibration of the terminal $-\mathrm{NH}_{2}$ groups, respectively [37]. A weak absorption peak was observed at $1400 \mathrm{~cm}^{-1}$ (peak 7) in N3-FA, which could be attributed to the stretching vibrational mode of $\mathrm{C}=\mathrm{C}$ groups present in FA molecules. The characteristic peaks at 1545 and $1647 \mathrm{~cm}^{-1}$ (peak 8 and 9) have been characterized as the stretching vibration mode of secondary amide bonds ( $\mathrm{C}=\mathrm{O}-\mathrm{NH})$.

Figure $2 \mathrm{~b}$ shows the TGA analysis of the different $\mathrm{Gd}_{2} \mathrm{O}_{3}: \mathrm{Eu}^{3+}$ nanoparticle systems. Weight loss in N2-APTMS and N3-FA at low temperature $\left(\leq 200{ }^{\circ} \mathrm{C}\right)$ was due to the dehydration of water molecules attached to the surface of nanoparticles. The weight loss due to the presence of organic moieties $\left(>200{ }^{\circ} \mathrm{C}\right.$ ) was estimated to be 3.78 and $5.53 \%$ for N2-APTMS and N3-FA, respectively. The higher weight loss in N3-FA compared to N2-APTMS is due to the conjugation of folic acid molecules onto the surface of N2-APTMS.

Conjugation of FA to APTMS coated nanoparticles was further confirmed by XPS analysis. Preliminary confirmation of FA conjugation was obtained through the presence of an intense nitrogen peak in N3-FA compared to N2-APTMS, due to the presence of 7 nitrogen atoms in FA molecule (Additional file 1: Figure S1). Additionally, the high-resolution spectrum of C 1s of N2-APTMS 

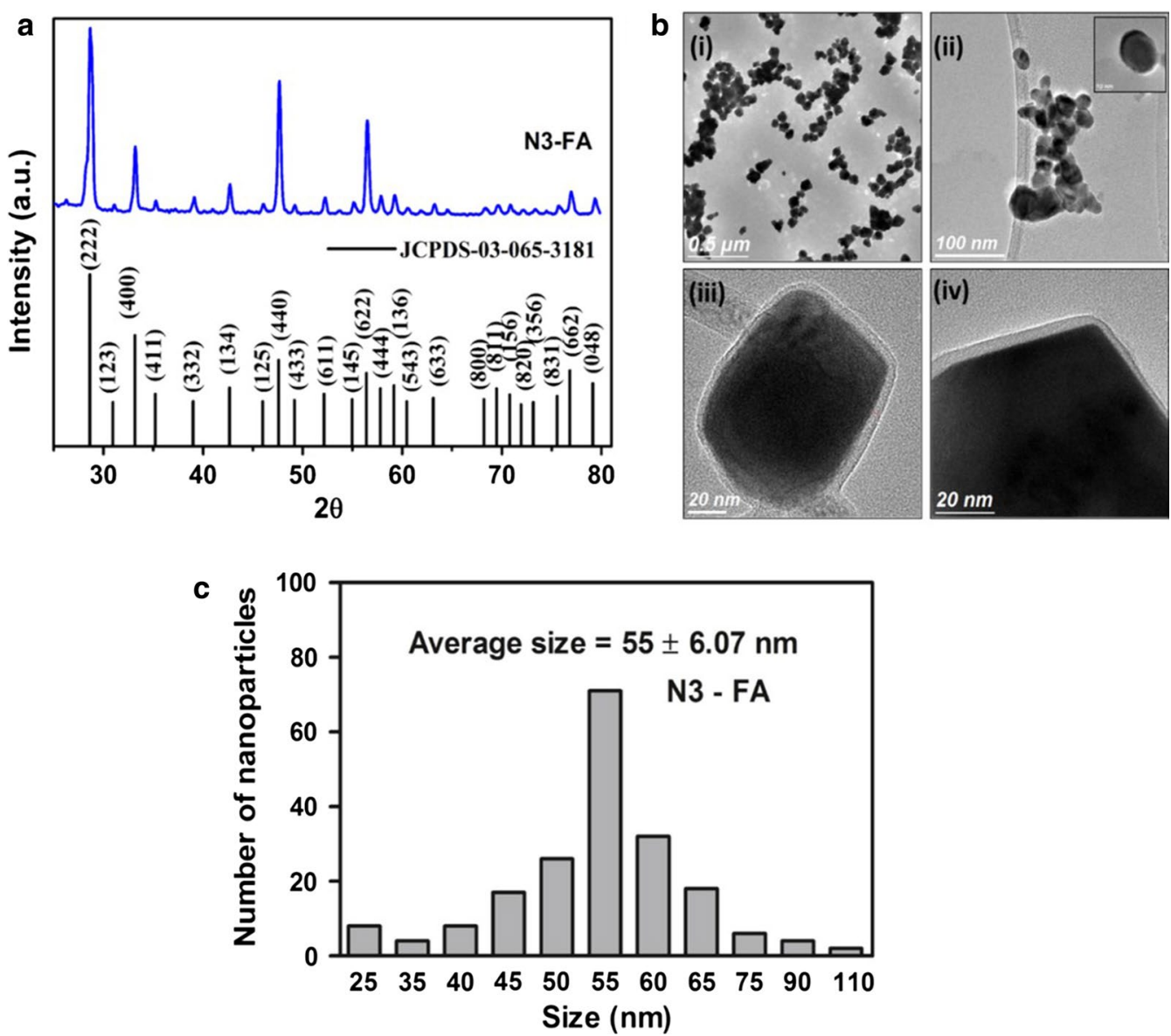

Fig. 1 Characterization of $\mathrm{Gd}_{2} \mathrm{O}_{3}: \mathrm{Eu}^{3+}$ nanoparticles. a X-Ray diffraction pattern of N3-FA. b TEM images (i and ii) N1-Bare (iii and iv) N3-FA. c Histogram of particle size distribution of N3-FA obtained from TEM analysis

and N3-FA are shown in Fig. 2c, d. Deconvolution of C $1 \mathrm{~s}$ showed the existence of amide bond in N3-FA. The C 1s spectrum of N3-FA was well fitted into five peaks located at 282.8, 284.4, 285.2, 286.3 and $288.4 \mathrm{eV}$. The lowest binding energy (B.E.) component $(282.8 \mathrm{eV})$ was associated with peaks that arise due to the presence of $\mathrm{C}-\mathrm{Si}$ bonds in APTMS molecules. Higher B.E. components at 284.4, 285.2 and $286.3 \mathrm{eV}$ has been assigned to $\mathrm{C}-\mathrm{C} / \mathrm{C}=\mathrm{C}, \mathrm{C}-\mathrm{O}$ and $\mathrm{C}-\mathrm{NH}_{3}{ }^{+} / \mathrm{C}-\mathrm{NH}$ bonds [38], the presence of these peaks can be seen in both APTMS coated (Fig. 2c) and FA-functionalized $\mathrm{Gd}_{2} \mathrm{O}_{3}: \mathrm{Eu}^{3+}$ nanoparticles (Fig. 2d). In addition, another higher energy component at $288.4 \mathrm{eV}$ (Fig. 2d) was obtained specifically in N3-FA, which corresponds to the backbone of amide bond $(\mathrm{NH}-\mathrm{C}=\mathrm{O})$ [38]. The presence of peak due to amide bonding confirms the successful conjugation of $\mathrm{NH}_{2}$ groups of $\mathrm{Gd}_{2} \mathrm{O}_{3}: \mathrm{Eu}^{3+}$ @ APTMS (N2-APTMS) with $-\mathrm{COO}^{-}$groups of FA.

The nanoparticle surface charge is directly influenced by the chemical composition of the coating, which also affects the stability of nanoparticles in aqueous solution. The colloidal stability of the different $\mathrm{Gd}_{2} \mathrm{O}_{3}: \mathrm{Eu}^{3+}$ nanoparticle system (N1-Bare, N2-APTMS, and N3-FA) was determined by measuring zeta potential in PBS (Table 1). The obtained values indicated a weak colloidal stability of $\mathrm{Gd}_{2} \mathrm{O}_{3}: \mathrm{Eu}^{3+}$ nanoparticles (N1-Bare) in PBS. However, the colloidal stability was improved after surface functionalization with APTMS (N2-APTMS) and folic acid (N3-FA), which could be due to the introduction of surface reactive amine groups. We further determined the hydrodynamic diameter of the nanoparticles using DLS. The hydrodynamic diameter of N1-bare was around $126 \mathrm{~nm}$ indicating the presence of agglomeration between the nanoparticles (Table 1). The hydrodynamic diameter of N2-APTMS and N3-FA nanoparticles was increased to 134 and $143 \mathrm{~nm}$, respectively, due to the introduction of silane layer and functionalization process. The polydispersity index (PDI) values of $\mathrm{Gd}_{2} \mathrm{O}_{3}: \mathrm{Eu}^{3+}$ nanoparticle system was in the range of $0.27-0.31$, thus indicating mid-range of particle size distribution. Overall, 

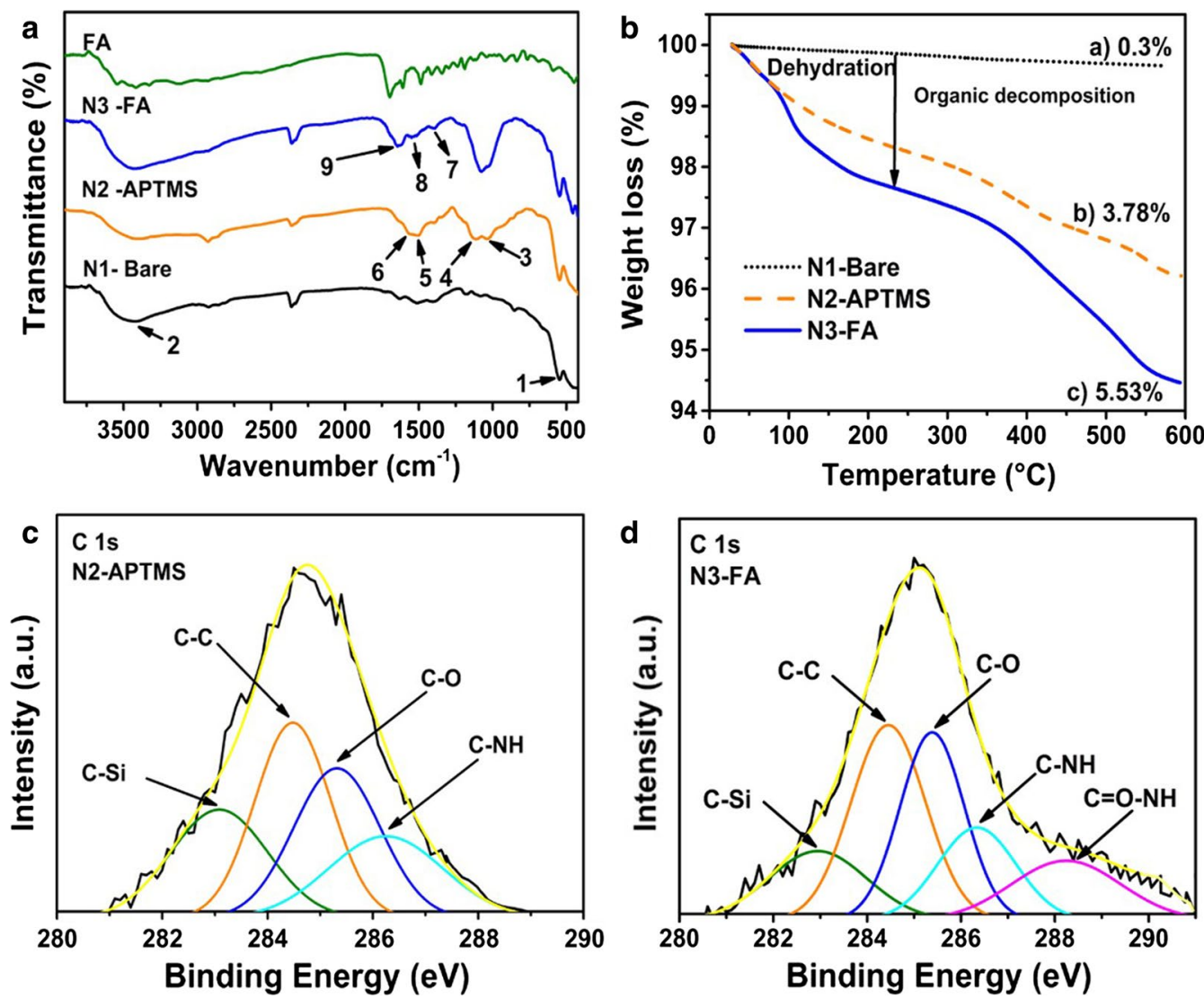

Fig. 2 Surface characterization of $\mathrm{Gd}_{2} \mathrm{O}_{3}: \mathrm{Eu}^{3+}$ nanoparticles. a FTIR spectra, b TGA curves of unmodified (N1-bare), APTMS coated (N2-APTMS), and folic acid-functionalized $\mathrm{Gd}_{2} \mathrm{O}_{3}$ :Eu ${ }^{3+}$ nanoparticles (N3-FA); high-resolution C $1 \mathrm{~s}$ XPS spectra of $\mathbf{c}$ N2-APTMS and $\mathbf{d}$ N3-FA

Table 1 Hydrodynamic diameter (d), zeta potential (ל) and polydispersity index of different $\mathrm{Gd}_{2} \mathrm{O}_{3}: \mathrm{Eu}^{3+}$ nanoparticles

\begin{tabular}{|c|c|c|c|}
\hline \multirow[t]{2}{*}{ Particle system } & \multicolumn{3}{|l|}{ PBS (pH 7.4) } \\
\hline & $\zeta(\mathrm{mV})$ & $d(n m)$ & PDI \\
\hline N1-Bare & $+9.9 \pm 3.22$ & 126 & 0.315 \\
\hline N2-APTMS & $+16.2 \pm 1.05$ & 134 & 0.298 \\
\hline N3-FA & $+23.2 \pm 1.84$ & 143 & 0.279 \\
\hline
\end{tabular}

Error bars represent the standard deviation of three individual experiments. All the measurements were performed in PBS ( $\mathrm{pH} 7.4)$

these results confirmed the synthesis of FA-functionalized $\mathrm{Gd}_{2} \mathrm{O}_{3}: \mathrm{Eu}^{3+}$ nanoparticles with optimal dispersion property.

\section{Photoluminescence (PL) properties}

Rare-earth (RE) doped down-conversion luminescent nanoparticles have been extensively studied due to their unique optical properties. We have characterized the quantum yield, photoluminescence excitation/emission spectra, quantum yield, and fluorescence lifetime of the proposed $\mathrm{Gd}_{2} \mathrm{O}_{3}: \mathrm{Eu}^{3+}$ nanoparticle system for cancer detection and bio-imaging. Quantum yield (QY) is an essential parameter required for high contrast bioimaging and defines the photoluminescence efficiency of a nanophosphor. It is well known that the efficiency of a radiative recombination process is directly proportional to the quantum yield. Figure 3a shows the effect of $\mathrm{Eu}^{3+}$ doping concentration on the QY of $\mathrm{Gd}_{2} \mathrm{O}_{3}: \mathrm{Eu}^{3+}$ nanoparticles. The QY of the nanoparticles reached its highest value of $\sim 40 \%$ at a $\mathrm{Eu}^{3+}$ concentration of $5 \%$. Above $5 \%$, a decrease in the QY was observed, which could be attributed to luminescence concentration quenching. At these europium concentrations, the distance between the neighboring activator ions $\left(\mathrm{Eu}^{3+}\right)$ becomes smaller causing $\mathrm{Eu}^{3+}$ ions to move around the host lattice causing resonant energy transfer thus sending excitation energy to the quenching center. The quantum yield of different $\mathrm{Gd}_{2} \mathrm{O}_{3}: \mathrm{Eu}^{3+}\left(\mathrm{Eu}^{3+}\right.$ doping concentration $\left.=5 \%\right)$ nanoparticle system was determined in the aqueous colloidal form using rhodamine $6 \mathrm{G}$ as a reference standard (Table 2). A maximum of $\sim 42 \%$ QY was obtained 

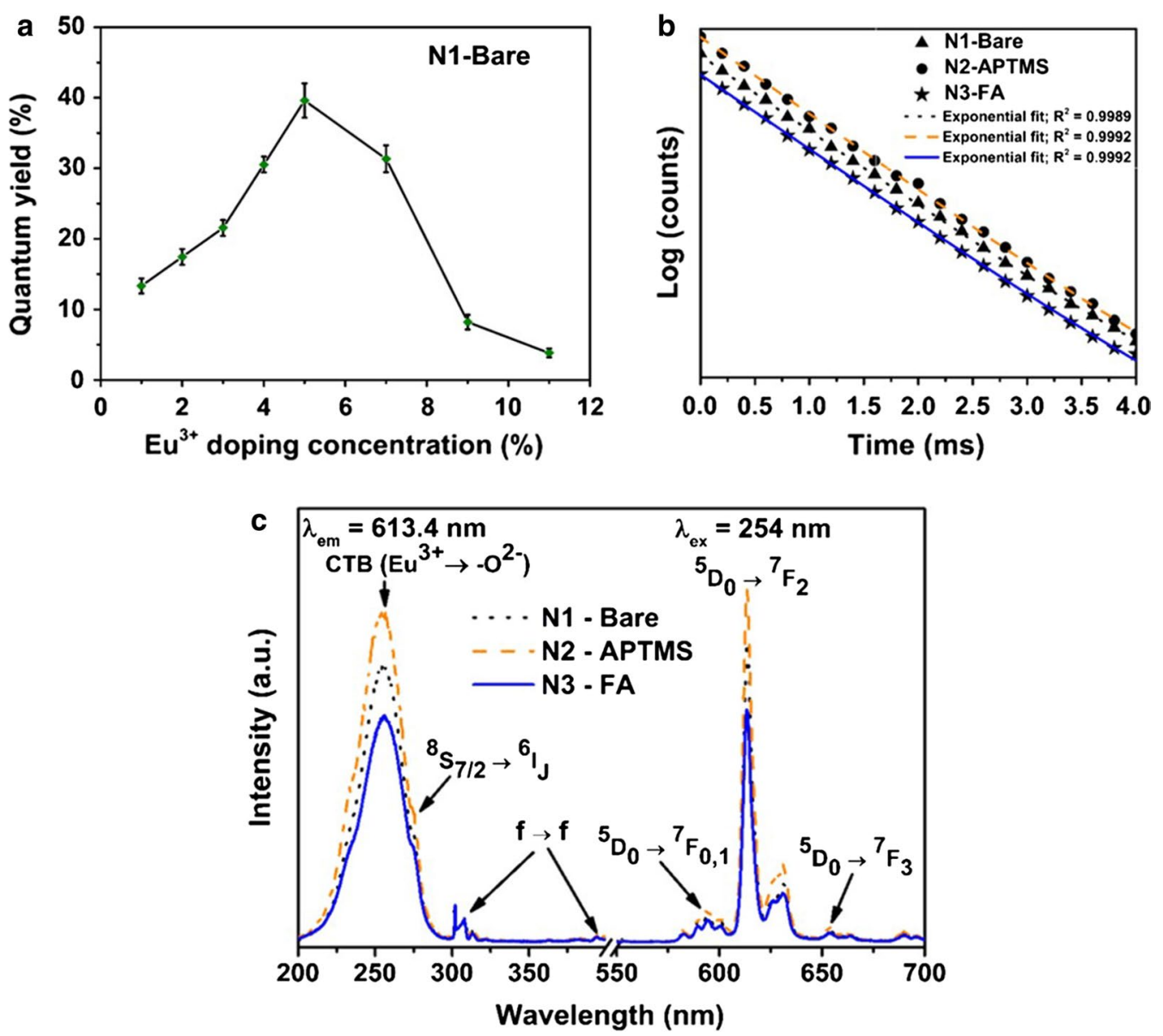

Fig. 3 Photoluminescence properties of $\mathrm{Gd}_{2} \mathrm{O}_{3}: \mathrm{Eu}^{3+}$ nanoparticles. a Quantum yield of $\mathrm{Gd}_{2} \mathrm{O}_{3}: \mathrm{Eu}^{3+}$ as a function of Eu ${ }^{3+}$ doping concentration, $\mathbf{b}$ fluorescent decay time curves, and $\mathbf{c}$ photoluminescence excitation and emission spectra. All the measurements were performed in PBS (pH 7.4)

Table 2 Average decay time and absolute quantum yield values of different $\mathrm{Gd}_{2} \mathrm{O}_{3}: \mathrm{Eu}^{3+}$ nanoparticle system measured in aqueous colloidal form

\begin{tabular}{lll}
\hline Nanoparticle system & Average decay time (ms) & QY (\%) \\
\hline N1-Bare & $1.076 \pm 0.003$ & $39.6 \pm 2.43$ \\
N2-APTMS & $1.114 \pm 0.002$ & $41.4 \pm 3.03$ \\
N3-FA & $1.061 \pm 0.006$ & $35.3 \pm 1.79$ \\
\hline
\end{tabular}

Error bars represent the standard deviation of three individual experiments

for N2-APTMS, which is slightly higher than N1-bare nanoparticles $(\sim 40 \%)$ indicating that surface coating with amino-silane increase the radiative emission from $\mathrm{Gd}_{2} \mathrm{O}_{3}: \mathrm{Eu}^{3+}$ nanoparticles. On the other hand, the calculated value of QY for FA-functionalized nanoparticles (N3) was $\sim 35 \%$, indicating that the folic acid functionalization causes an increase in non-radiative emission process. Furthermore, fluorescence lifetime $(\tau)$ measurements were carried out, which is an important parameter for overcoming the background auto-fluorescence [39]. The lifetime decay curves of different $\mathrm{Gd}_{2} \mathrm{O}_{3}: \mathrm{Eu}^{3+}$ nanoparticles system is shown in Fig. 3b. The calculated average fluorescence lifetime $\left(\tau_{\mathrm{av}}\right)$ values of the $\mathrm{Gd}_{2} \mathrm{O}_{3}: \mathrm{Eu}^{3+}$ nanoparticles (N1-Bare, N2-APTMS, and N3-FA) were around $\sim 1 \mathrm{~ms}$ (Table 2 ).

The photoluminescence excitation and emission spectra of the nanoparticle systems, measured in PBS is shown in Fig. 3c. The excitation spectra of $\mathrm{Gd}_{2} \mathrm{O}_{3}: \mathrm{Eu}^{3+}$ $\left(\mathrm{Eu}^{3+}\right.$ doping concentration $\left.=5 \%\right)$ nanoparticles consisted of three main excitation bands with peaks located at 254, 275 and at $394 \mathrm{~nm}$. The characteristic peak at $254 \mathrm{~nm}$ corresponds to the charge transfer band which arise due to the transfer of an electron to $4 \mathrm{f}$ orbital of europium from $2 \mathrm{p}$ orbital of oxygen. Other peaks observed at 275 and $394 \mathrm{~nm}$ are associated with $4 \mathrm{f}-4 \mathrm{f}$ electronic transitions of $\mathrm{Gd}^{3+}$ and $\mathrm{Eu}^{3+}$, respectively. The emission spectra was observed after excitation with $254 \mathrm{~nm}$, which produced the highest PL intensity. The observed emission bands are the result of the transition 
from ${ }^{5} \mathrm{D}_{0}$ excited state level of $\mathrm{Eu}^{3+}$ to ${ }^{7} \mathrm{~F}_{\mathrm{J}}(\mathrm{J}=0,1,2,3)$ ground state level. A group of peaks around $\sim 580 \mathrm{~nm}$ was attributed to the transition from ${ }^{5} \mathrm{D}_{0} \rightarrow{ }^{7} \mathrm{~F}_{0}$ and another peak located at $593 \mathrm{~nm}$ to magnetic dipole allowed by ${ }^{5} \mathrm{D}_{0} \rightarrow{ }^{7} \mathrm{~F}_{1}$ level. The observed red emission of $\mathrm{Gd}_{2} \mathrm{O}_{3}: \mathrm{Eu}^{3+}$ nanoparticle was due to the emission peak at $613.4 \mathrm{~nm}$, which is due to an electric dipole associated with ${ }^{5} \mathrm{D}_{0} \rightarrow{ }^{7} \mathrm{~F}_{2}$ transition of $\mathrm{Eu}^{3+}$. We observed variations in the PL emission intensity of N1-Bare, N2-APTMS and N3-FA systems. The PL emission intensity of $\mathrm{Gd}_{2} \mathrm{O}_{3}: \mathrm{Eu}^{3+}$ nanoparticles was increased after APTMS coating, which could be attributed to the removal of hydroxyl groups (Fig. 2a, peak 2), well known for quenching radiative process from nanophosphor materials. Additionally, the decrease in reflectivity of UV light from the surface of the nanoparticles due to the presence of silane layer could be another reason for the increased PL intensity. Finally, the PL intensity of N3-FA nanoparticles was decreased, which is probably due to the introduction of folic acid that contains a large number of organic groups. The high energetic vibration of organic groups near the surface of a nanophosphor has also been shown to reduce PL intensity by increasing non-radiative recombination process [40].

\section{In vitro cytotoxicity}

The significant photoluminescence and physicochemical properties of $\mathrm{Gd}_{2} \mathrm{O}_{3}: \mathrm{Eu}^{3+}$ nanoparticles encouraged us to study their potential in cancer imaging. As a first step, we determined the cytotoxic effect of $\mathrm{Gd}_{2} \mathrm{O}_{3}: \mathrm{Eu}^{3+}$ nanoparticles in vitro on the human breast cancer cells T-47D and the 293T cell line derived from normal human embryonic kidney cells. T-47D and 293T cells were cultured in the presence or absence of increasing concentrations of nanoparticles (N1-Bare, N2-APTMS, or N3-FA) and cell viability was evaluated after 24 or $48 \mathrm{~h}$ of treatment using a colorimetric MTT assay. A continuous $24 \mathrm{~h}$ - and $48 \mathrm{~h}$-treatment induced a significant time- and dose-dependent decrease of the viability of the two cell lines tested when compared to untreated cells, starting at a concentration as low as $6.25 \mu \mathrm{g} / \mathrm{ml}$ (Fig. 4). At lower concentrations, the decrease remained limited, reaching $20 \%$ after $48 \mathrm{~h}$, at $6.25 \mu \mathrm{g} / \mathrm{ml}$ for the $293 \mathrm{~T}$ cells. At higher concentrations, the decrease of viability was limited to $38 \%$ at $100 \mu \mathrm{g} / \mathrm{ml}$ of nanoparticles for T-47D, after $48 \mathrm{~h}$. Interestingly, there was no significant difference when comparing the different formulations of nanoparticles (N1-Bare, N2-APTMS, and N3-FA), suggesting that the
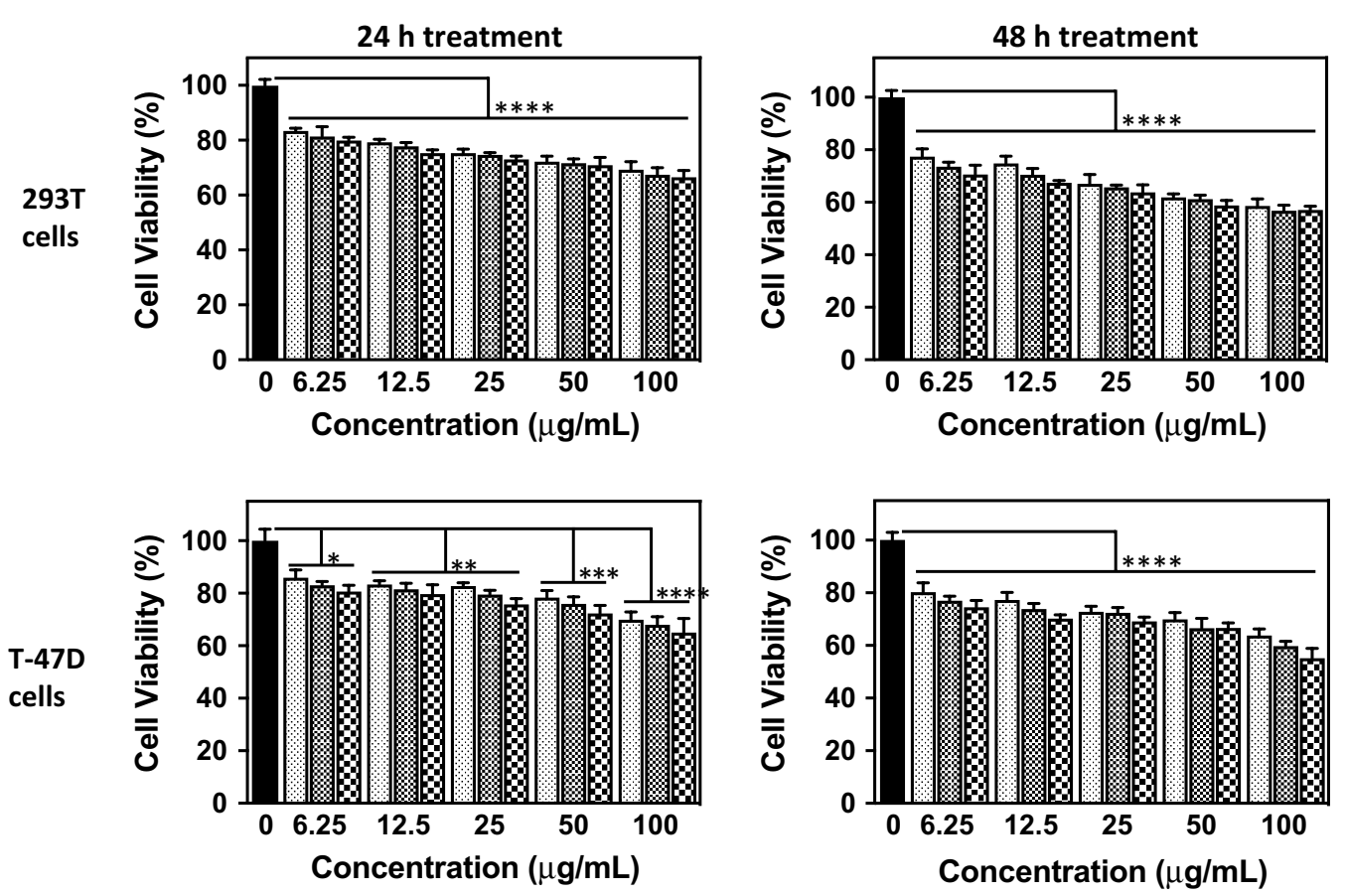

N1-Bare

㱫 N2-APTMS

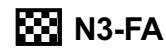

Fig. 4 Effect of $\mathrm{Gd}_{2} \mathrm{O}_{3}: \mathrm{Eu}^{3+}$ nanoparticles on cell viability. Human embryonic kidney cells 293T and human breast cancer cells T-47D were cultured in increasing concentration ofunmodified (N1-bare), APTMS coated (N2-APTMS), and folic acid-functionalized $\mathrm{Gd}_{2} \mathrm{O}_{3}$ :Eu ${ }^{3+}$ nanoparticles (N3-FA) for 24 or $48 \mathrm{~h}$, before measuring cell viability. The experiment was run in triplicate and OD570 nm is expressed as \% of control ( $0 \mu \mathrm{mg} / \mathrm{ml}$ nanoparticles). Results are expressed as the mean $\pm \mathrm{SEM}{ }^{*} \mathrm{P}<0.05 ;{ }^{* *} \mathrm{P}<0.01 ;{ }^{* *} \mathrm{P}<0.001$; and ${ }^{* * *} \mathrm{P}<0.0001$ obtained using 2 -way ANOVA with a Tukey post-test 
decreased viability was due to the core $\mathrm{Gd}_{2} \mathrm{O}_{3}: \mathrm{Eu}^{3+}$ nanoparticle itself and not the functionalization (Fig. 4).

\section{Folate receptor expression and cellular uptake}

To increase the affinity of the $\mathrm{Gd}_{2} \mathrm{O}_{3}: \mathrm{Eu}^{3+}$ nanoparticles for cancer cells and detect tumors but also to decrease the risk of internalization in normal, which could lead to toxicity and side-effects, it was decided to functionalize the nanoparticles with folic acid since its receptor, the folate receptor, is often overexpressed in cancer. To reproduce this in vitro, we sought to identify a cell line with a high expression of folate receptor $\left(F o l r 1^{h i}\right)$, and we determined the level of expression of folate receptor Folr 1 in different human cancer cell lines using RT-qPCR. T-47D human breast cancer cells showed a significantly higher expression of Folr1 when compared to kidney cells (293T) or other breast cancer cell lines (MCF-7 and MDA-MB-231) and prostate cancer cell line (PC-3) (Fig. 5a). To evaluate the targeting ability of FA-functionalized $\mathrm{Gd}_{2} \mathrm{O}_{3}: \mathrm{Eu}^{3+}$ nanoparticles (N3-FA), we examined their cellular uptake in T-47D $\left(\right.$ Folr $\left.1^{h i}\right)$ and MDA-MB-231 $\left(\right.$ Folr $\left.^{l o}\right)$ human breast cancer cell lines. After $2 \mathrm{~h}$ incubation, the red fluorescent signal from N3-FA of T-47D cells was strong and located inside the cytoplasm, while in MDA-MB-231 cells the fluorescence was mostly found on the outer membrane, and significantly lower than in T-47D cells, even after longer incubation time (Fig. 5b, c). On the contrary, the internalization of N3-FA nanoparticles into the cytoplasm of T-47D cell lines continuously increased with incubation time suggesting that the N3-FA nanoparticles were specifically internalized into T-47D cells. This difference in N3-FA uptake between Folr ${ }^{h i}$ and Folr ${ }^{l o}$ cells is likely due to the affinity of Folr1 towards the folic acid molecules conjugated to the surface of $\mathrm{Gd}_{2} \mathrm{O}_{3}: \mathrm{Eu}^{3+}$ nanoparticles. These results indicate the feasibility of using folic acid functionalized- $\mathrm{Gd}_{2} \mathrm{O}_{3}: \mathrm{Eu}^{3+}$ nanoparticles as an efficient fluorescent probe for cancer cell imaging and, eventually, targeted drug delivery.

\section{In vivo acute toxicity and pharmacokinetics of folic acid conjugated- $\mathrm{Gd}_{2} \mathrm{O}_{3}: \mathrm{Eu}^{3+}$ nanoparticles (N3-FA)}

First, we determine the highest dose of nanoparticles that could be tolerated by the animals, N3-FA were administered intravenously (i.v.) via the tail vein with increasing doses (from 35 to $300 \mathrm{mg} / \mathrm{kg}$ ) in CD1 mice. The symptoms of preliminary response to the nanoparticle

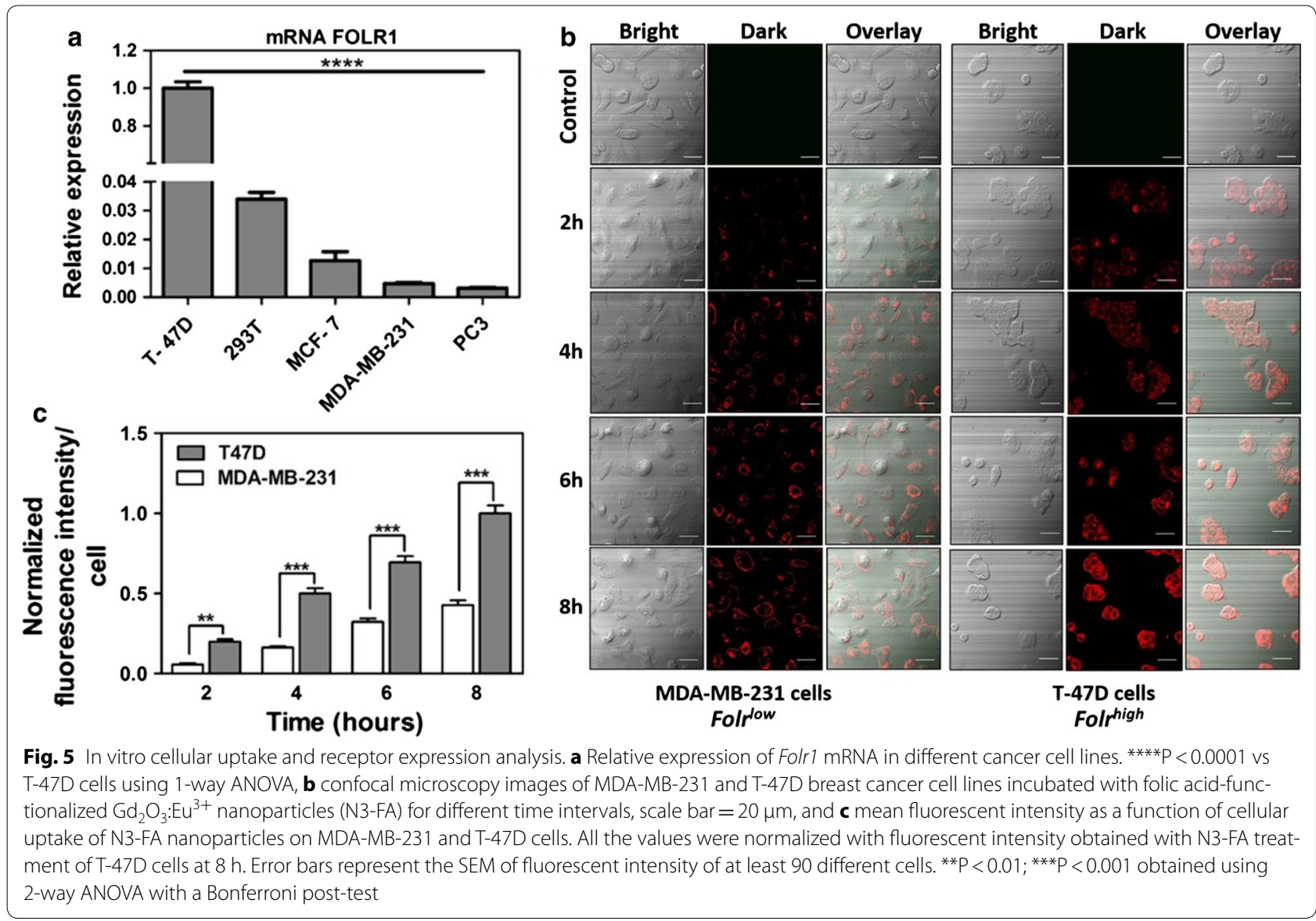


injection, behavior pattern, food and water intake, and change in body weight were monitored until 7 days. The percentage of change in body weight of the mice during the course of the experiment is shown in Fig. 6a. We found that there was no significant difference in the body weight of the mice injected with N3-FA compared to control mice that received PBS. In addition, food or water intake were not different in mice that received N3-FA compared with control (Additional file 1: Figure S3) and none of the mice inoculated died regardless of N3-FA dose, suggesting that even at high dose nanoparticles were well tolerated in mice.

Next, we question for how long we can find the nanoparticles in the blood circulation. Taking into account the

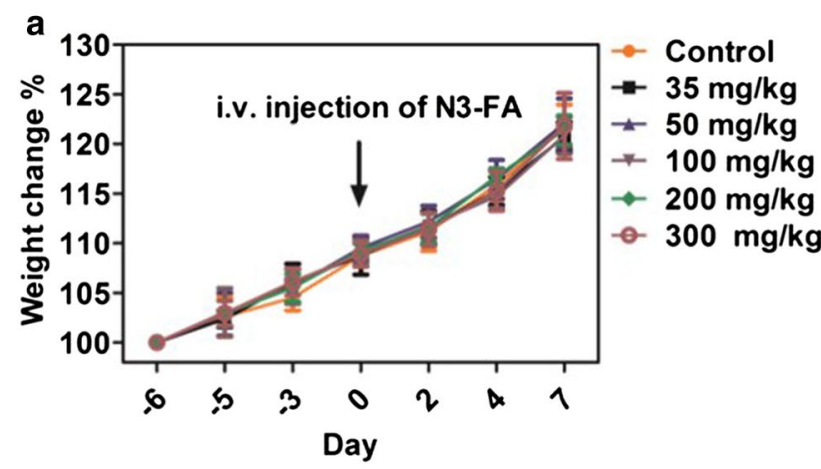

\section{c Control}
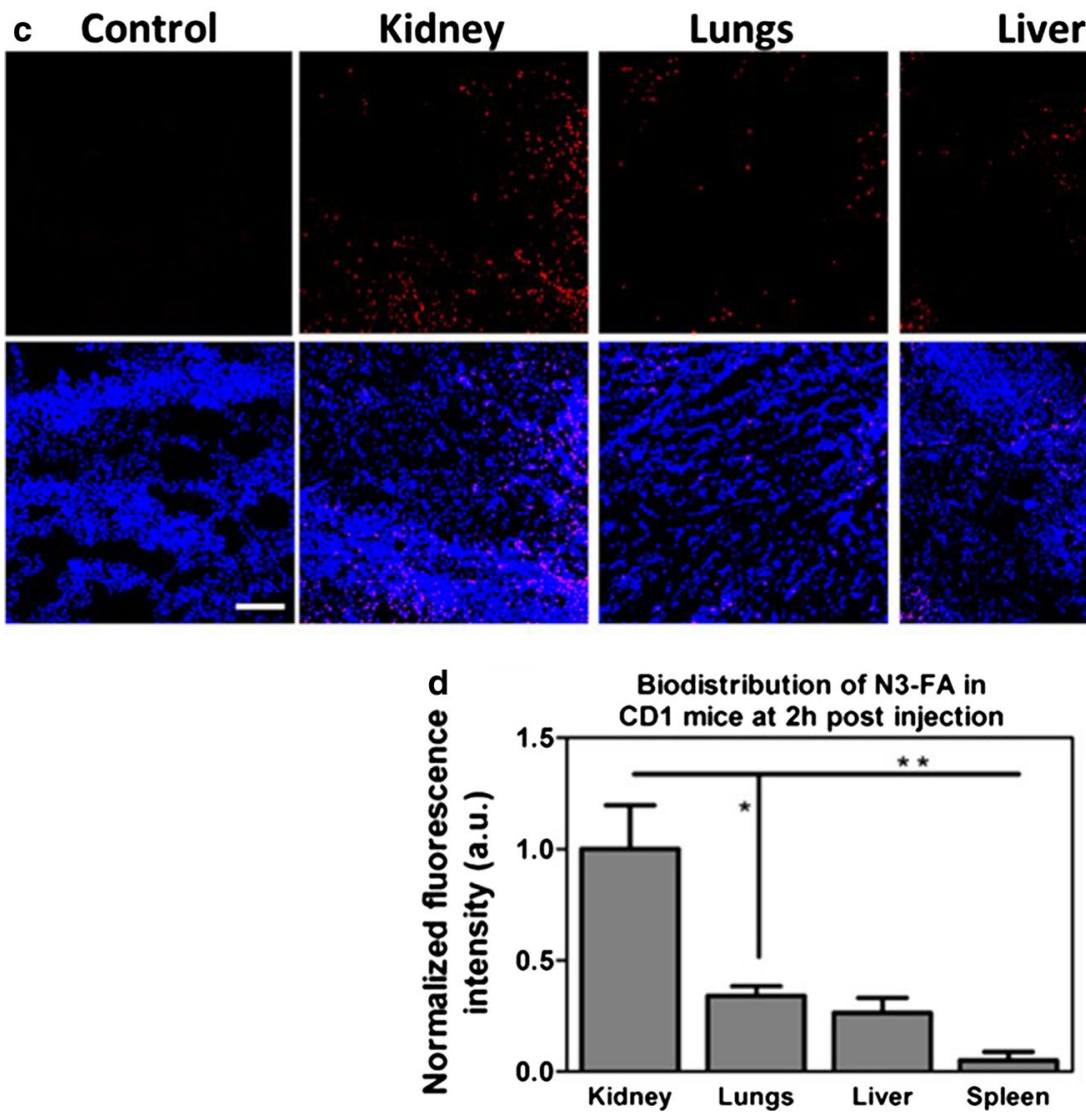

Fig. 6 Acute toxicity and pharmacokinetic characterization of folic acid-functionalized $\mathrm{Gd}_{2} \mathrm{O}_{3}$ :Eu ${ }^{3+}$ nanoparticles (N3-FA) in CD1 mice. a Change in body weight of CD1 mice after i.v. injection of N3-FA at different doses, $\mathbf{b}$ detection of N3-FA in whole blood of CD1 mice using fluorescent spectrophotometer at various time intervals, c biodistribution of N3-FA in different organs of CD1 mice 2 h after i.v. injection at a dose of 200 mg/kg, analyzed using CLSM of tissue sections, Scale bar $=50 \mu \mathrm{m}$, and $\mathbf{d}$ mean fluorescent intensity as a function of N3-FA accumulation in different organs of CD1 mice. * ${ }^{*}<0.05 ;{ }^{* *} \mathrm{P}<0.01$ vs kidney using 1-way ANOVA with a Bonferroni post-test 
optimal QY of N3-FA, their presence in blood samples of CD1 mice after i.v. injection was analyzed by monitoring their emission spectra. Figure $6 \mathrm{~b}$ shows that the nanoparticles were detected in whole blood up to $2 \mathrm{~h}$ after inoculation, which could be attributed to rapid clearance of N3-FA from blood circulation. Further, in vivo biodistribution of N3-FA nanoparticles was analyzed in different organs of CD1 mice, $2 \mathrm{~h}$ after intravenous injection. N3-FA was detected in kidneys, liver, lungs, and spleen (Fig. 6c, d). Highest levels of N3-FA were detected in kidneys, while liver and lungs showed a lower, but similar accumulation. Spleen presented very weak fluorescence signal, suggesting poor uptake of N3-FA by spleen cells. The significantly higher accumulation of N3-FA in kidney compared to other organs suggests their rapid metabolism and clearance from the body (Fig. 6d). The presence of nanoparticles in liver, lungs, and spleen has been attributed to the distribution of mononuclear phagocytes [25].

\section{Biodistribution and tumor-targeting ability of folic acid-conjugated $\mathrm{Gd}_{2} \mathrm{O}_{3}: \mathrm{Eu}^{3+}$ nanoparticles in breast cancer xenograft models analyzed using CLSM}

To evaluate the targeting potential of FA-conjugated nanoparticles in tumor-bearing mice, we inoculated T-47D $\left(F o l r 1^{h i}\right)$ and MDA-MB-231 cells $\left(F o l r 1^{l o}\right)$ in immunodeficient mice. The mice bearing T-47D tumors were injected either with N3-FA $(n=3)$ or N2-APTMS ( $\mathrm{n}=3$; control), and the mice with MDA-MB-231 tumors were injected with N3-FA $(n=3)$. Organs of the mice were collected $2 \mathrm{~h}$ post injection of nanoparticles, and their distribution was analyzed using CLSM. A strong fluorescence was detected in T-47D tumors injected with N3-FA (Fig. 7a), indicating fast tumor uptake. In contrast, N2-APTMS showed poor accumulation in tumors compared to N3-FA, this is due to the fact that N2-APTMS do not have folic acid-functionalization and their accumulation would be solely due to the EPR effect. Furthermore, N3-FA showed poor accumulation in MDA-MB-231 tumors, which could be attributed to the relatively low levels of folate receptors (Fig. 7b). These results showed that active targeting of folate receptors using N3-FA significantly increased its accumulation in T-47D tumors $\left(\right.$ Folr $1^{\text {hi }}$ ) compared to the N2-APTMS. Moreover, poor uptake in MDA-MB-231 tumors (Fol$r 1^{l o}$ ) demonstrated high specificity of FA-conjugated $\mathrm{Gd}_{2} \mathrm{O}_{3}: \mathrm{Eu}^{3+}$ nanoparticles (N3-FA) towards folate receptor-expressing tumors. Figure 7c shows CLSM images of different organs of tumor-bearing mice. A high fluorescent signal in kidney was observed in all mouse groups irrespective of the mice model and the type of nanoparticles injected, suggesting that $\mathrm{Gd}_{2} \mathrm{O}_{3}: \mathrm{Eu}^{3+}$ nanoparticles are mainly metabolized through the urinary system. In a similar way that was observed in CD1 mice, diffused distribution of N2-APTMS and N3-FA was seen in lungs, liver, and spleen. Further, quantification of fluorescent intensity (Fig. 7d) confirmed that N2-APTMS and N3-FA have similar uptake profile in kidney, while the non-specific uptake by lungs and liver is significantly reduced after folic acid functionalization. Overall, these results demonstrate the targeting potential of FA-conjugated $\mathrm{Gd}_{2} \mathrm{O}_{3}: \mathrm{Eu}^{3+}$ nanoparticles (N3-FA) in vivo and confirm their specificity towards Folr ${ }^{h i}$ tumors such as those observed in intra-ductal carcinoma.

\section{Tumor accumulation of $\mathrm{Gd}_{2} \mathrm{O}_{3}: \mathrm{Eu}^{3+}$ nanoparticles analyzed using $\mathrm{CT}$ imaging}

Computed tomography $(\mathrm{CT})$ is one of the most powerful and clinically used techniques to detect tumors. CT possesses the advantage of obtaining unlimited penetration depth that allows the detection of deep lying tumors. Therefore, we hypothesized that a combination of $\mathrm{CT}$ and fluorescence imaging using $\mathrm{FA}-\mathrm{Gd}_{2} \mathrm{O}_{3}: \mathrm{Eu}^{3+}$ nanoparticles would enhance the in vivo tumor detection. Mice bearing T-47D or MDA-MB-231 subcutaneous tumors received an i.v. inoculation of either N3-FA or N2-APTMS. Two hours later the mice were euthanized and the tumors were extracted to carry out CT imaging. Intense $\mathrm{CT}$ signals due to the presence of $\mathrm{Gd}_{2} \mathrm{O}_{3}: \mathrm{Eu}^{3+}$ nanoparticles were observed in tumors (Fig. 8a). As expected the signal and the amount of nanoparticles was significantly higher in T-47D tumors when the nanoparticles were functionalized with folic acid (N3-FA) when compared to the signal due to N2-APTMS nanoparticles. In addition the amount of N3-FA nanoparticles was significantly lower in MDA-MB-231 tumors that have low expression of Folr1 when compared to T-47D tumors that are having high expression the receptor (Fig. 8a, b). Together, these results demonstrate the specificity of FA-conjugated $\mathrm{Gd}_{2} \mathrm{O}_{3}: \mathrm{Eu}^{3+}$ nanoparticles towards Folr ${ }^{\mathrm{hi}}$ tumors and their potential as a targeted CT imaging agent for clinical applications.

\section{Discussion}

Breast cancer is the most common cause of cancerrelated death among women, and it is estimated that more than 40,000 women in the USA alone will die because of it in 2017 [41]. To increase the chances of successful treatment or survival, it is critical to detect breast cancer as early as possible. Despite the progress in screening with mammography, there is still a significant amount of false-negative results (10-25\%) that will lead to therapeutic delay, thus increasing the risk of developing metastasis by the time of detection [42]. Therefore, the development of new diagnostic tools for breast cancer detection is of vital importance. We reported here the 


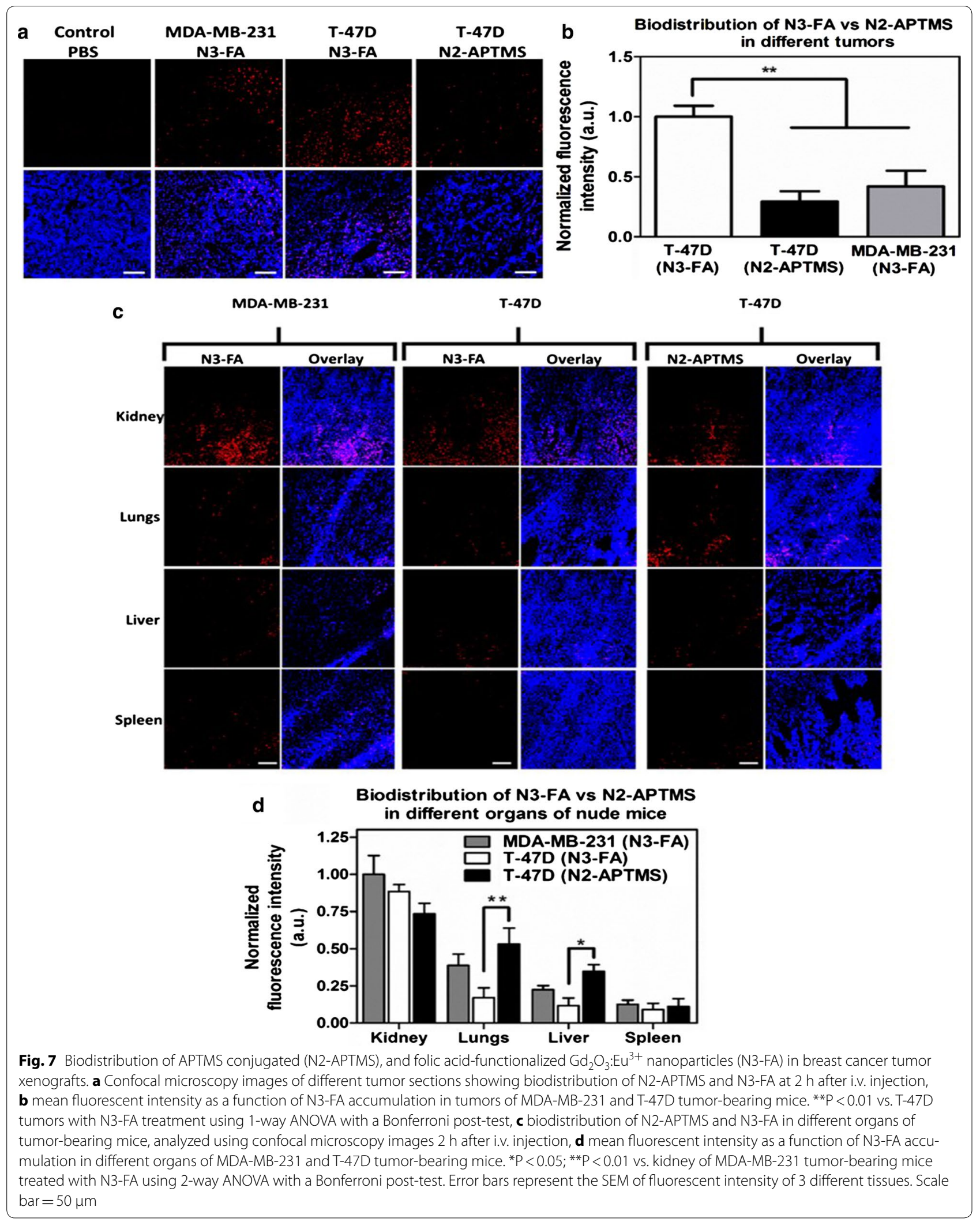



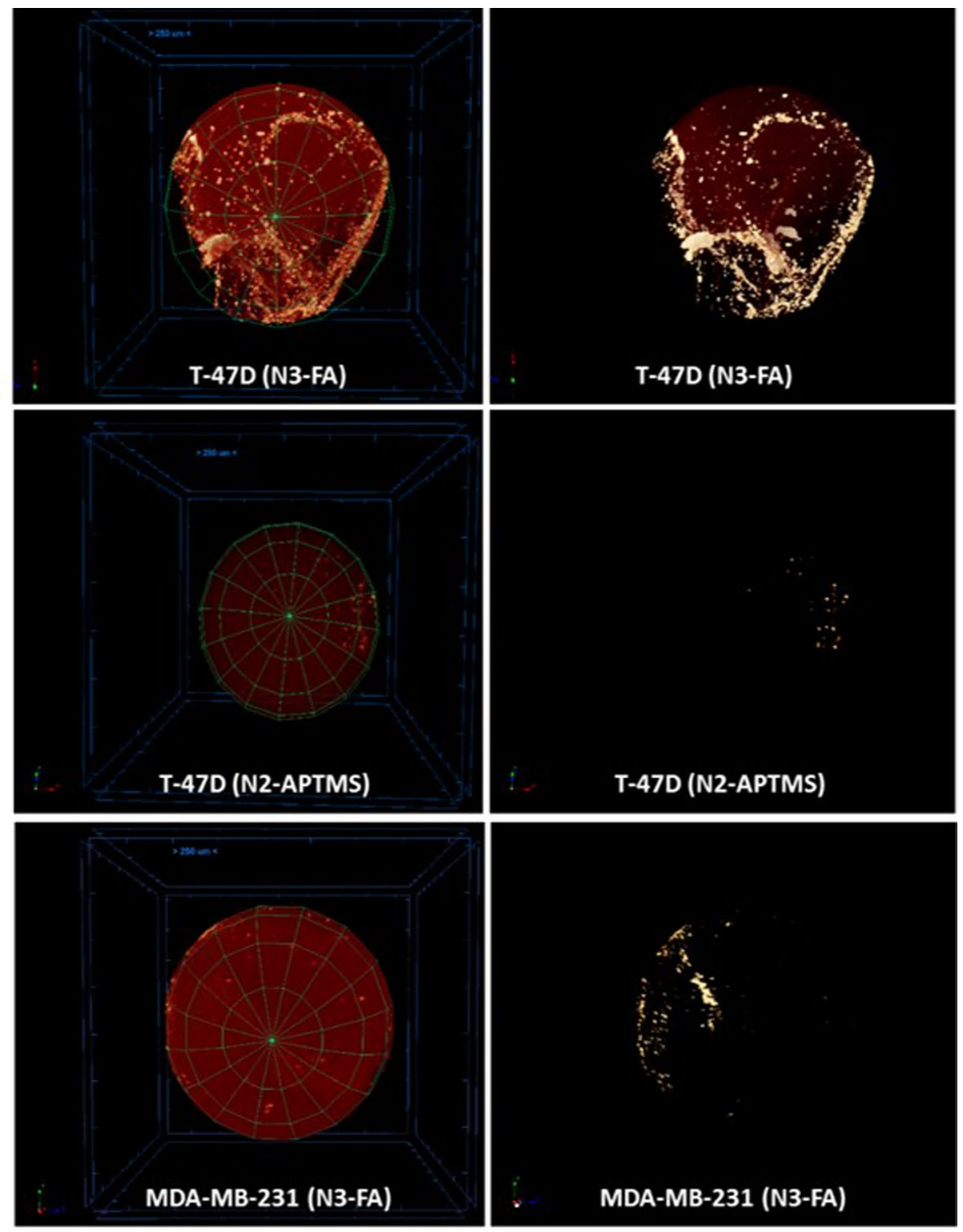

b

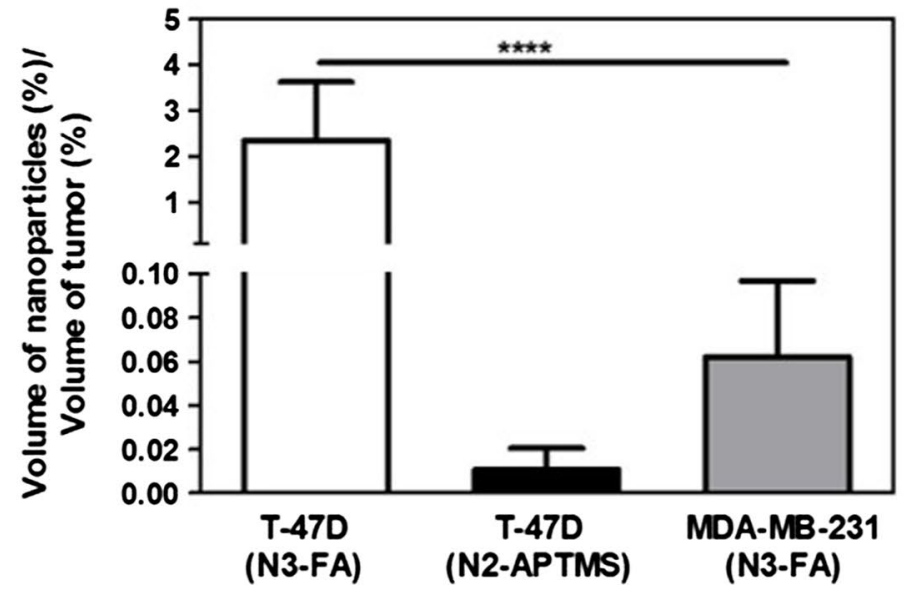


(See figure on previous page.)

Fig. 8 Biodistribution of APTMS conjugated (N2-APTMS), and folic acid-functionalized $\mathrm{Gd}_{2} \mathrm{O}_{3}$ :Eu ${ }^{3+}$ nanoparticles (N3-FA) in breast cancer tumors. $\mathbf{a}$ CT images of different tumors showing biodistribution of N2-APTMS and N3-FA at $2 \mathrm{~h}$ after i.v. injection, $\mathbf{b}$ quantification data representing \% volume of tumors occupied by \% volume of $\mathrm{Gd}_{2} \mathrm{O}_{3}: \mathrm{Eu}^{3+}$ nanoparticles. ${ }^{* * *} \mathrm{P}<0.0001$ vs. T-47D tumors with N3-FA treatment using 1-way ANOVA with a Bonferroni post-test

development and characterization of folic acid-functionalized luminescent $\mathrm{Gd}_{2} \mathrm{O}_{3}: \mathrm{Eu}^{3+}$ nanoparticles as a new diagnostic tool for breast cancer detection alone or in combination with $\mathrm{CT}$ imaging.

$\mathrm{Gd}_{2} \mathrm{O}_{3}: \mathrm{Eu}^{3+}$ nanocrystals were produced using sucrose combustion synthesis, and nanoparticles exhibited good crystallinity, narrow size distribution, and optimal quantum yield. Compared to other conventional synthesis methods of $\mathrm{Gd}_{2} \mathrm{O}_{3}: \mathrm{Eu}^{3+}$ nanoparticles such as sol-gel, hydrothermal and spray pyrolysis, combustion synthesis is a low cost and rapid synthesis procedure to produce nanoparticles with improved photoluminescence properties $[43,44]$. The QY of the synthesized nanoparticles strongly depended upon the doping concentration of the activator ion $\left(\mathrm{Eu}^{3+}\right)$. We found $5 \% \mathrm{Eu}^{3+}$ was optimum to obtain highest QY ( 41\%) and an average decay time of $\sim 1 \mathrm{~ms}$. Surface functionalization with folic acid reduced the QY of $\mathrm{Gd}_{2} \mathrm{O}_{3}: \mathrm{Eu}^{3+}$ nanoparticles to $35 \%$ due to increased non-radiative recombination process. Nevertheless, the obtained values indicate that FA-conjugated $\mathrm{Gd}_{2} \mathrm{O}_{3}$ : $\mathrm{Eu}^{3+}$ nanoparticles (N3-FA) are a good candidate for in vivo bioimaging.

Most of the nanoparticles used for drug delivery or cancer imaging application are $50-150 \mathrm{~nm}$ in diameter in order to take advantage of the passive targeting of tumor vasculature via EPR effect [45]. The specificity and efficiency of nanoparticles can be improved by surface modification with a specific targeting ligand. In view of that, the surface of $\mathrm{Gd}_{2} \mathrm{O}_{3}: \mathrm{Eu}^{3+}$ was functionalized with folic acid to target Folr1, which is frequently over-expressed in breast cancers. The average size of the FA-conjugated nanoparticles (N3-FA) was $55 \pm 6 \mathrm{~nm}$, which lies in the size range for passive targeting via EPR effect. The produced nanoparticles can then use both passive and active targeting to reach the cancer cells. Surface charge is important to avoid agglomeration of the particles that are electrostatically stabilized in suspensions. Zeta potential measurements showed that N1-Bare have poor colloidal stability in PBS with a value of $+9.9 \pm 3.22 \mathrm{mV}$, which could be attributed to the lack of surface reactive groups, such as $-\mathrm{OH}$. However, colloidal stability was improved after surface functionalization with APTMS and FA, reaching a zeta potential of $+23.2 \pm 1.84 \mathrm{mV}$ for N3-FA, indicating a decreased risk of aggregation. Overall, N3-FA nanoparticles combine a good size for passive targeting to tumors in vivo as well as a limited risk of aggregation, which is an important characteristic for systemic delivery in patients.

We further showed that FA-functionalized $\mathrm{Gd}_{2} \mathrm{O}_{3}: \mathrm{Eu}^{3+}$ nanoparticles had low cytotoxic effect in vitro at concentrations up to $50 \mu \mathrm{g} / \mathrm{ml}$. A slight decrease in cell viability was induced quickly after addition of the nanoparticles, even at low concentration $(6.25 \mu \mathrm{g} / \mathrm{ml})$ and kept increasing over time. Since this decrease was quickly induced, it seems likely that the nanoparticles could partly stop cell cycle and proliferation. Additional experiments would be require to study this matter and, at the moment, we cannot discard the possibility of inducing apoptosis if the treatment was prolonged. However, since the primary goal with this nanoparticle is diagnostic, a single injection would be given to patients. The distribution of the signal would then be measured and the nanoparticles would be cleared out of the body hence reducing the risks of continuous exposure and the induction of serious side effects. This is conforted by the fact that in vivo, N3-FA nanoparticles were well tolerated in mice, with doses up to $300 \mathrm{mg} / \mathrm{kg}$, as there was no mortality or change in body weight during the course of the study. In rats, a single injection of gold nanoparticles, eventually led to side effects almost a month after the inoculation, due to their coating [46]. Additional experiments in a different model, with longer time of study would be needed to clear out this possibility. In the meantime, these results suggested a good biocompatibility of N3-FA, encouraging further research for an application as tumor detection markers.

To assess the targeting potential of these nanoparticles Folr ${ }^{\text {hi }}$ cancer cells, we used a combination of in vitro and in vivo characterization using fluorescence and $\mathrm{CT}$ imaging. In vitro, N3-FA nanoparticles had a faster and significantly higher uptake in Folr ${ }^{\text {hi }}$ cancer cells like T-47D compared to Folr ${ }^{\text {lo }}$ cancer cells such as MDA-MB-231. Similarly in tumor-bearing mice, systemically delivered N3-FA nanoparticles accumulated preferentially in T-47D tumors when compared to MDA-MB-231 tumors. This distribution was due to the expression of Folr1 on cancer cells and the presence of FA on the nanoparticles since there was significantly less uptake in T-47D tumors when N2-APTMS were injected. Accumulation of N3-FA and N2-APTMS nanoparticles in MDA-MB-231 and T-47D tumors, respectively, is likely due to passive EPR effect. In addition, the presence of fluorescence in the tumors $2 \mathrm{~h}$ after the inoculation indicated that there was 
retention of the nanoparticles since, at this time, it was not possible to detect nanoparticles in blood circulation. The absence of nanoparticles in the blood after $2 \mathrm{~h}$, also indicated a fast clearance of the nanoparticles, which minimizes the risk of toxic response [47]. In normal tissues, fluorescence was detected in the kidneys, probably due to renal clearance of the nanoparticles. However, there were few, or no N3-FA detected in lungs, liver or spleen in tumor-bearing mice, indicating reduced uptake in non-cancerous tissues, which is required for a cancer probe. CT imaging analysis demonstrated that the combination of CT imaging with N3-FA nanoparticles significantly enhanced tumor detection.

\section{Conclusion}

In summary, we have described the development of folic acid-conjugated $\mathrm{Gd}_{2} \mathrm{O}_{3}: \mathrm{Eu}^{3+}$ nanoparticles with low toxicity that can be used as a fluorescent probe for the detection of Folr1 breast cancer in vivo. Our work provides major evidence that justify future research focused towards the clinical application of FA-conjugated $\mathrm{Gd}_{2} \mathrm{O}_{3}: \mathrm{Eu}^{3+}$ for detection of breast cancer using optical imaging. In combination with CT scans, it would be possible to achieve high-resolution imaging and detection of deeply located tumors.

\section{Additional file}

Additional file 1. Additional figures.

\section{Authors' contributions \\ AJ performed all the experiments. AJ, PF, GH, and PJ conceived the idea and designed the experiments. FG assisted to RNA preparation and qRT-PCR experiments. VL, El, TK assisted in acquiring and analyzing CT imaging data. PS assisted to the in vivo cytotoxicity experiments. AJ, PF, GH, PJ analyzed and interpreted the obtained data. AJ, PF, GH, and PJ wrote, reviewed the manu- script. All authors read and approved the final manuscript.}

\begin{abstract}
Author details
${ }^{1}$ Biomedical Innovation Department, Centro de Investigación Científica y de Educación Superior de Ensenada (CICESE), Carretera Ensenada-Tijuana No. 3918, Zona Playitas, C.P. 22860 Ensenada, B.C., Mexico. ${ }^{2}$ Posgrado en Física de Materiales, Centro de Investigación Científica y de Educación Superior de Ensenada (CICESE), Carretera Ensenada-Tijuana No. 3918, Zona Playitas, C.P. 22860 Ensenada, B.C., Mexico. ${ }^{3}$ Universidad Nacional Autónoma de México (UNAM)-Centro de Nanociencias y Nanotecnología (CNyN), Km. 107 Carretera Tijuana-Ensenada, C.P. 22860 Ensenada, B.C., Mexico. ${ }^{4}$ Departamento de Geología, Centro de Investigación Cientíica y de Educación Superior de Ensenada (CICESE), Carretera Transpeninsular Ensenada-Tijuana \#318, Zona Playitas, C.P. 22860 Ensenada, B.C., Mexico. ${ }^{5}$ Centro Mexicano de Innovación en Energía Geotérmica (CeMIGeo), Rinconada del Pedregal 95, Pedregal Playitas, 22860 Ensenada, Baja California, Mexico.
\end{abstract}

\section{Acknowledgements}

AJ and PS are grateful to CONACyT for Ph.D. scholarship. The authors would like to thank Eloisa Aparicio Ceja, Francisco Ruiz Medina, David Dominguez, Olga Alicia Callejas-Negrete and Deyanira Rodarte Venegas for their invaluable technical support.
Competing interests

The authors declare that they have no competing interests.

Availability of data and materials

Data sharing not applicable to this article as no datasets were generated or analyzed during the current study.

\section{Consent for publication}

Not applicable.

\section{Ethics approval and consent to participate}

All animal experiments were performed in compliance with the local ethics committee (CICESE).

\section{Funding}

The authors acknowledge financial support from CONACyT Grant No. 247892 and CICESE Grant No. 985-105 to P.J.; DGAPA-UNAM Grant No. IN111017 and CONACyT Grant No. 232608 to G.H.

\section{Publisher's Note}

Springer Nature remains neutral with regard to jurisdictional claims in published maps and institutional affiliations.

Received: 23 September 2017 Accepted: 19 March 2018

Published online: 22 March 2018

\section{References}

1. Prabhakar U, Maeda H, Jain RK, Sevick-Muraca EM, Zamboni W, Farokhzad $O C$, et al. Challenges and key considerations of the enhanced permeability and retention effect for nanomedicine drug delivery in oncology. Cancer Res. 2013;73:2412-7.

2. Popovtzer R. Targeted gold nanoparticles enable molecular CT imaging of cancer: an in vivo study. Int J Nanomed. 2011;6:2859.

3. Natarajan A, Gruettner C, Ivkov R, Denardo GL, Mirick G, Yuan A, et al. NanoFerrite particle based radioimmunonanoparticles: binding affinity and in vivo pharmacokinetics. Bioconjug Chem. 2008;19:1211-8.

4. Sun X, Cai W, Chen X. Positron emission tomography imaging using radiolabeled inorganic nanomaterials. Acc Chem Res. 2015;48:286-94.

5. Rahmim A, Zaidi H. PET versus SPECT: strengths, limitations and challenges. Nucl Med Commun. 2008;29:193-207.

6. Weissleder R. Scaling down imaging: cancer in mice. Nat Rev. 2002;2:1-8.

7. Pericleous P, Gazouli M, Lyberopoulou A, Rizos S, Nikiteas N, Efstathopoulos EP. Quantum dots hold promise for early cancer imaging and detection. Int J Cancer. 2012;131:519-28.

8. Herranz M, Ruibal A. Optical imaging in breast cancer diagnosis: the next evolution. J Oncol. 2012;2012:863747.

9. Lu M, Zhang W, Gai Y, Yang T, Ye P, Yang G, et al. Folate-PEG functionalized silica CdTe quantum dots as fluorescent probes for cancer cell imaging. New J Chem. 2014;38:4519-26.

10. Yin F, Zhang B, Zeng S, Lin G, Tian J, Yang C, et al. Folic acid-conjugated organically modified silica nanoparticles for enhanced targeted delivery in cancer cells and tumor in vivo. J Mater Chem B. 2015;3:6081-93.

11. Eggeling C, Widengren J, Rigler R, Seidel CA. Photobleaching of fluorescent dyes under conditions used for single-molecule detection: evidence of two-step photolysis. Anal Chem. 1998;70:2651-9.

12. Liu T, Xing R, Zhou YF, Zhang J, Su YY, Zhang KQ, et al. Hematopoiesis toxicity induced by CdTe quantum dots determined in an invertebrate model organism. Biomaterials. 2014;35:2942-51.

13. Shen J, Sun LD, Yan CH. Luminescent rare earth nanomaterials for bioprobe applications. Dalton Trans 2008;(42):5687-97. https://doi. org/10.1039/B805306E.

14. Bouzigues C, Gacoin T, Alexandrou A. Biological applications of rare-earth based nanoparticles. ACS Nano. 2011;5:8488-505.

15. Khachatourian AM, Golestani-fard F, Sarpoolaky H, Vogt C, Toprak MS Microwave assisted synthesis of monodispersed $\mathrm{Y}_{2} \mathrm{O}_{3}$ and $\mathrm{Y}_{2} \mathrm{O}_{3}: \mathrm{Eu}^{3+}$ particles. Ceram Int. 2015;41:2006-14. 
16. Méndez M, Carvajal JJ, Cesteros Y, Aguiló M, Díaz F, Gigure A, et al. Sol-gel pechini synthesis and optical spectroscopy of nanocrystalline $\mathrm{La}_{2} \mathrm{O}_{3}$ doped with $\mathrm{Eu}^{3+}$. Opt Mater. 2010;32:1686-92.

17. Lin CC, Lin KM, LiYY. Sol-gel synthesis and photoluminescent characteristics of $\mathrm{Eu}^{3+}$-doped $\mathrm{Gd}_{2} \mathrm{O}_{3}$ nanophosphors. J Lumin. 2007;126:795-9.

18. Xiao H, Li P, Jia F, Zhang L. General nonaqueous sol-gel synthesis of nanostructured $\mathrm{Sm}_{2} \mathrm{O}_{3}, \mathrm{Gd}_{2} \mathrm{O}_{3}, \mathrm{Dy}_{2} \mathrm{O}_{3}$, and $\mathrm{Gd}_{2} \mathrm{O}_{3}$ : $\mathrm{Eu}^{3+}$ Phosphor. J Phys Chem C. 2009;113:21034-41.

19. Louis C, Bazzi R, Marquette CA, Bridot JL, Roux S, Ledoux G, et al. Nanosized hybrid particles with double luminescence for biological labeling. Chem Mater. 2005;17:1673-82.

20. Kyung Cha B, Muralidharan P, Jun Lee S, Kim DK, Cho G, Jeon S, et al. Hydrothermal synthesis, structure and scintillation characterization of nanocrystalline $\mathrm{Eu}_{3}$-doped $\mathrm{Gd}_{2} \mathrm{O}_{3}$ materials and its $X$-ray imaging applications. Nucl Instr Methods Phys Res Sect A Accel Spectrom Detect Assoc Equip. 2011;652:212-5.

21. Bedekar V, Dutta DP, Mohapatra M, Godbole SV, Ghildiyal R, Tyagi AK. Rare-earth doped gadolinia based phosphors for potential multicolor and white light emitting deep UV LEDs. Nanotechnology. 2009:20:125707.

22. Liu J, Tian X, Luo N, Yang C, Xiaal J, Shao Y, Chen X, Yang G, Chen D, Li L. Sub-10 nm monoclinic $\mathrm{Gd}_{2} \mathrm{O}_{3}: \mathrm{Eu}^{3+}$ nanoparticles as dual-modal nanoprobes for magentic resonance and fluorescence imaging. Langmuir. 2014;30:13005-12.

23. Li Q, Lin J, Wu J, Lan Z, Wang J, Wang Y, Peng F, Huang M, Xiao Y. Preparation of $\mathrm{Gd}_{2} \mathrm{O}_{3}: \mathrm{Eu}^{3+}$ downconversion luminescent material and its application in dye-sensitized solar cells. Chin Sci Bull. 2011;56:3114-8.

24. Tang Y, Han S, Liu H, Chen X, Huang L, Li X, et al. The role of surface chemistry in determining invivo biodistribution and toxicity of CdSe/ZnS core-shell quantum dots. Biomaterials. 2013;34:8741-55.

25. Huang X, Li L, Liu T, Hao N, Liu H, Chen D, et al. The shape effect of mesoporous silica nanoparticles on biodistribution. ACS Nano. 2011;5:5390-9.

26. Schleich N, Po C, Jacobs D, Ucakar B, Gallez B, Danhier F, et al. Comparison of active, passive and magnetic targeting to tumors of multifunctional paclitaxel/SPIO-loaded nanoparticles for tumor imaging and therapy. J Control Release. 2014;194:82-91.

27. Sykes EA, Chen J, Zheng G, Chan WC. Investigating the impact of nanoparticle size on active and passive tumor targeting efficiency. ACS Nano. 2014;8:5696-706

28. Chen D, Li B, Cai S, Wang P, Peng S, Sheng Y, et al. Dual targeting luminescent gold nanoclusters for tumor imaging and deep tissue therapy. Biomaterials. 2016;100:1-16.

29. Parker N, Turk MJ, Westrick E, Lewis JD, Low PS, Leamon CP. Folate receptor expression in carcinomas and normal tissues determined by a quantitative radioligand binding assay. Anal Biochem. 2005;338:284-93.

30. Kelemen LE. The role of folate receptor alpha in cancer development, progression and treatment: cause, consequence or innocent bystander? Int J Cancer. 2006;119:243-50.

31. Saha A, Mohanta SC, Deka K, Deb P, Devi PS. Surface-engineered multifunctional $\mathrm{Eu}: \mathrm{Gd}_{2} \mathrm{O}_{3}$ nanoplates for targeted and $\mathrm{PH}$-responsive drug delivery and imaging applications. ACS Appl Mater Interfaces. 2017:9:4126-41.
32. Ma Y-Y, Ding $\mathrm{H}$, Xiong H-M. Folic acid functionalized $\mathrm{ZnO}$ quantum dots for targeted cancer cell imaging. Nanotechnology. 2015;26:305702.

33. Setua S, Menon D, Asok A, Nair S, Koyakutty M. Folate receptor targeted rare-earth oxide nanocrystals for bi-modal fluorescence and magnetic imaging of cancer cells. Biomaterials. 2010;31:714-29.

34. Stefanakis D, Ghanotakis FD. Rare earth fluorescent nanoparticles for specific cancer cell targeting. J Nanopart Res. 2016;18:177.

35. Jain A, Hirata GA. Photoluminescence, size and morphology of redemitting $\mathrm{Gd}_{2} \mathrm{O}_{3}: \mathrm{Eu}^{3+}$ nanophosphor synthesized by various methods. Ceram Int. 2016;42:6428-35.

36. Kömpe K, Borchert H, Storz J, Lobo A, et al. Green-emitting CePO 4 :Tb/ $\mathrm{LaPO}_{4}$ core-shell nanoparticles with 70\% photoluminescence quantum yield. Angew Chem Int Ed. 2003:42:5513-6.

37. Pasternack RM, Amy SR, Chabal YJ. Attachment of 3-(aminopropyl) triethoxysilane on silicon oxide surfaces: dependence on solution temperature. Langmuir. 2008;7:12963-71.

38. Eby DM, Artyushkova K, Paravastu K, Johnson GR. Probing the molecular structure of antimicrobial peptide-mediated silica condensation using X-ray photoelectron spectroscopy. J Mater Chem. 2012;22:9875-83.

39. Berezin MY, Achilefu S. fluorescence lifetime measurements and biological imaging. Chem Rev. 2010;110:2641-84.

40. Stouwdam JW, van Veggel FCJM. Improvement in the luminescence properties and processability of $\mathrm{LaF}_{3} / \mathrm{Ln}$ and $\mathrm{LaPO}_{4} / \mathrm{Ln}$ nanoparticles by surface modification. Langmuir ACS J Surf Colloids. 2004;20:11763-71.

41. Siegel RL, Miller KD, Jemal A. Cancer statistics. CA Cancer J Clin. 2016;66:7-30

42. Hathaway HJ, Butler KS, Adolphi NL, Lovato DM, Belfon R, Fegan D, et al. Detection of breast cancer cells using targeted magnetic nanoparticles and ultra-sensitive magnetic field sensors. Breast Cancer Res. 2011;13:R108.

43. Kopp Alves A, Bergmann CP, Berutti FA. Novel synthesis and characterization of nanostructured materials. 2013;92.

44. Lee S, Choi JI, Kim YJ, Han JK, Ha J, Novitskaya E, et al. Comparison of luminescent properties of $\mathrm{Y}_{2} \mathrm{O}_{3}: \mathrm{Eu}^{3+}$ and $\mathrm{LaPO}_{4}: \mathrm{Ce}^{3+}, \mathrm{Tb}^{3+}$ phosphors prepared by various synthetic methods. Mater Charact. 2015;103:162-9.

45. Maeda H, Wu J, Sawa T, Matsumura Y, Hori K. Tumor vascular permeability and the EPR effect in macromolecular therapeutics: a review. J Control Release. 2000;65:271-84.

46. Fraga S, Brandão A, Soares ME, Morais T, Duarte JA, Pereira L, Soares L, Neves C, Pereira E, Bastos Mde L, Carmo H. Short- and long-term distribution and toxicity of gold nanoparticles in the rat after a single-dose intravenous administration. Nanomedicine. 2014;10:1757-66.

47. Longmire M, Choyke PL, Kobayashi H. Clearance properties of nano-sized particles and molecules as imaging agents: considerations and caveats. Nanomedicine. 2012;3:703-17.

\section{Submit your next manuscript to BioMed Central and we will help you at every step:}

- We accept pre-submission inquiries

- Our selector tool helps you to find the most relevant journal

- We provide round the clock customer support

- Convenient online submission

- Thorough peer review

- Inclusion in PubMed and all major indexing services

- Maximum visibility for your research

Submit your manuscript at www.biomedcentral.com/submit 